\title{
Density Functional Theory studies of HCOOH decomposition on Pd(111)
}

\author{
Jessica Scaranto and Manos Mavrikakis* \\ Department of Chemical and Biological Engineering \\ University of Wisconsin-Madison, 1415 Engineering Drive, Madison, WI, 53706, USA \\ *corresponding author: emavrikakis@wisc.edu
}

\begin{abstract}
The investigation of formic acid $(\mathrm{HCOOH})$ decomposition on transition metal surfaces is important to derive useful insights for vapor phase catalysis involving $\mathrm{HCOOH}$ and for the development of direct $\mathrm{HCOOH}$ fuel cells (DFAFC). Here we present the results obtained from periodic, self-consistent, density functional theory (DFT-GGA) calculations for the elementary steps involved in the gas-phase decomposition of $\mathrm{HCOOH}$ on $\mathrm{Pd}(111)$. Accordingly, we analyzed the minimum energy paths for $\mathrm{HCOOH}$ dehydrogenation to $\mathrm{CO}_{2}+\mathrm{H}_{2}$ and dehydration to $\mathrm{CO}+\mathrm{H}_{2} \mathrm{O}$ through the carboxyl $(\mathrm{COOH})$ and formate $(\mathrm{HCOO})$ intermediates. Our results suggest that $\mathrm{HCOO}$ formation is easier than $\mathrm{COOH}$ formation, but $\mathrm{HCOO}$ decomposition is more difficult than $\mathrm{COOH}$ decomposition, in particular in the presence of co-adsorbed $\mathrm{O}$ and $\mathrm{OH}$ species. Therefore, both paths may contribute to $\mathrm{HCOOH}$ decomposition. $\mathrm{CO}$ formation goes mainly through $\mathrm{COOH}$ decomposition.
\end{abstract}

Keywords: Density Functional Theory; Formic acid; Pd(111); Decomposition; Formate; Carboxyl. 


\section{Introduction}

The study of formic acid $(\mathrm{HCOOH})$ decomposition on transition metals is important for gaining insights into vapor phase catalysis involving $\mathrm{HCOOH}[1]$. $\mathrm{HCOOH}$ represents a byproduct in the production of levulinic acid from $\operatorname{HMF}[2,3]$ and the hydrogen produced in situ from $\mathrm{HCOOH}$ degradation may be used to convert levulinic acid into fuels. The study of $\mathrm{HCOOH}$ decomposition can also provide important insights for the electro-oxidation of $\mathrm{HCOOH}$ at the anode of direct $\mathrm{HCOOH}$ fuel cells (DFAFC).

In the early 1960's, Sachtler et al.[4] investigated the catalytic decomposition of $\mathrm{HCOOH}$ vapors on metals using infrared (IR) spectroscopy, adsorption calorimetry and kinetic measurements. They assumed that the decomposition starts with the dissociative adsorption of $\mathrm{HCOOH}$ into formate $(\mathrm{HCOO})$ and hydrogen since they observed the presence of adsorbed HCOO with IR. Plotting the catalytic activity of metals in this reaction against the heat of formate formation on each metal, they obtained a volcano plot with the most active metal characterized by an intermediate value of the formate heat of formation. According to their analysis, Pt and Pd represent two of the most promising metals, which is also true for the most active metals used as the anode in DFAFC[5-13].

$\mathrm{HCOOH}$ electro-oxidation on Pt is usually explained as a dual-path mechanism[10, 14-19] which was originally proposed by Capon et al.[20, 21]: the indirect pathway leads to CO formation, followed by its electro-oxidation to $\mathrm{CO}_{2}$; the direct pathway involves the direct formation of $\mathrm{CO}_{2}$ (without producing $\mathrm{CO}$ ). $\mathrm{CO}$ production during $\mathrm{HCOOH}$ electro-oxidation represents a significant problem for Pt-based fuel cells since the adsorbed CO acts as a poison, limiting the FC operation. Pd-based DFAFC seem to suffer less from CO formation. In fact, using IR, Hoshi et al. did not detect $\mathrm{CO}$ adsorbed on a Pd surface and suggested that Pd single 
crystals do not allow $\mathrm{CO}$ formation during $\mathrm{HCOOH}$ electro-oxidation [22]. Using electromodulated infrared reflectance spectroscopy (EMIRS), Nishimura et al. did not find CO adsorbed on Pd and PdAu alloy electrodes [23]. Finally, using Fourier Transform Infrared Spectroscopy (FTIR), Arenz et al. did not observe vibrational features for Pd-CO in their study of $\mathrm{HCOOH}$ oxidation on Pt-Pd bimetallic surfaces [24]. However, Wang et al. observed the presence of $\mathrm{CO}$ from $\mathrm{HCOOH}$ decomposition $\mathrm{Pd}$ electrodes using high-sensitivity in situ surface-enhanced IR spectroscopy with attenuated total reflection (ATR-SEIRAS) and suggested that $\mathrm{CO}$ formation goes through the reduction of the dehydrogenation product $\mathrm{CO}_{2}[25]$.

The direct $\mathrm{CO}_{2}$ formation occurs through an active intermediate which derives from $\mathrm{HCOOH}$ dehydrogenation and may be either formate ( $\mathrm{HCOO})$ or carboxyl $(\mathrm{COOH})$. However, only HCOO intermediate has been observed in experiments on Pt and Pd surfaces, using various techniques, such as low energy electron diffraction (LEED)[26] , IR[15, 16, 23], surface-enhanced infrared absorption spectroscopy (SEIRAS)[27-31] and EMIRS[23, 32] .

To the best of our knowledge, there are few computational studies of $\mathrm{HCOOH}$ decomposition on $\operatorname{Pd}(111)$ [33-37]: in general, the identification of the reactive intermediate is still controversial; for example, $\mathrm{Hu}$ et al.[34] found $\mathrm{HCOO}$ as main intermediate for $\mathrm{HCOOH}$ decomposition, whereas Zhang et al.[37] suggested that both $\mathrm{HCOO}$ and $\mathrm{COOH}$ are involved in $\mathrm{HCOOH}$ dehydrogenation. Here we report a detailed investigation of gas-phase $\mathrm{HCOOH}$ decomposition on $\operatorname{Pd}(111)$ using Density Functional Theory (DFT-GGA). In this work, we consider not only $\mathrm{HCOOH}$ decomposition on the clean surface but also $\mathrm{HCOO}$ and $\mathrm{COOH}$ decomposition in the presence of co-adsorbed species such as $\mathrm{O}, \mathrm{OH}$ and $\mathrm{CO}$. The possible steps leading to the formation of $\mathrm{CO}_{2}$ and $\mathrm{CO}$ from both $\mathrm{HCOO}$ and $\mathrm{COOH}$ have been taken into account, as well as the path for $\mathrm{CO}$ production directly from $\mathrm{HCOOH}$. The main goal is to 
elucidate the role of the $\mathrm{HCOO}$ and $\mathrm{COOH}$ intermediates, and to gain insights into the mechanism of $\mathrm{CO}$ formation. This study also helps with the understanding of HCOOH electrooxidation on $\mathrm{Pd}$, which can be further improved by including electrode potential and other corrections accounting for the more complex electro-catalytic environment[38].

\section{Methods}

All the calculations have been carried out using the DACAPO total energy calculation code $[39,40]$. The $\operatorname{Pd}(111)$ surface has been modeled by a 3 -atomic layers slab using a $(3 \times 3)$ unit cell, corresponding to a surface coverage $(\theta)$ of $1 / 9 \mathrm{ML}$ for each adsorbate per unit cell. Since the surface relaxation has been proved to be negligible for similar systems[41-44], all the calculations have been performed by keeping Pd atoms fixed in their bulk truncated positions. Ultrasoft Vanderbilt pseudopotentials[45] have been adopted to describe core electron interactions and the Kohn-Sham one-electron valence states have been expanded on a basis of plane waves with kinetic energies below 25 Ry. Having checked convergence, the surface Brillouin zone was sampled at 6 special k-points[46]. The exchange-correlation energy and potential have been described using the PW91 generalized gradient approximation (PW91-GGA) $[47,48]$. The calculated lattice constant for bulk $\operatorname{Pd}$ is $3.99 \AA$, in reasonable agreement with the

experimental value (3.89 ̊) [49]. All reported energetics do not account for zero point energy corrections (ZPE). In fact, the ZPE was found to have minimal effect on the reaction energies of key elementary steps (e.g. dehydrogenation of $\mathrm{HCOOH}, \mathrm{HCOO}$ and $\mathrm{COOH}$ species)[50].

The binding energy (BE) of surface intermediates has been determined according to the following equation:

$\mathrm{BE}_{\mathrm{x}}=\mathrm{E}_{\text {slab }+\mathrm{x}}-\mathrm{E}_{\text {slab }}-\mathrm{E}_{\mathrm{x}}$ 
where $E_{s l a b+x}, E_{s l a b}$ and $E_{x}$ are the total energies of the adsorbate-substrate system, the clean slab and the gas-phase intermediate $\mathrm{x}$, respectively. According to the equation, a negative (positive) value of $\mathrm{BE}_{\mathrm{x}}$ means the adsorption is a favorable (unfavorable) process.

The minimum energy paths and the corresponding activation energy barriers have been calculated using the climbing image nudge elastic band method (CI-NEB) [51-53]. The path for each elementary step has been discretized by a total of nine images, including the initial and final states. Each path has been determined by considering the most stable (best) initial and final states, unless otherwise specified. The transition states were verified by calculating the corresponding vibrational frequencies and identifying a single negative curvature mode.

The vibrational frequencies of adsorbed species were determined using the harmonic oscillator assumption by diagonalization of the mass-weighted Hessian matrix in internal coordinates[54]. Initial, final and transition states are indicated in the text as I.S., F.S. and T.S., respectively. B.I.S. and B.F.S. indicate best initial state and best final state, respectively.

\section{Results and Discussion}

The elementary steps analyzed for $\mathrm{HCOOH}$ decomposition on the clean surface are shown in Scheme 1. Steps considered for the decomposition of $\mathrm{HCOO}$ and $\mathrm{COOH}$ in the presence of coadsorbed species are shown in Scheme 2. The following steps for $\mathrm{H}_{2} \mathrm{O}$ activation and $\mathrm{CO}$ oxidation were also studied:

$\mathrm{O}^{*}+\mathrm{H}^{*} \rightarrow * \mathrm{OH}+*$

$* \mathrm{OH}+\mathrm{H}^{*} \rightarrow \mathrm{H}_{2} \mathrm{O} *+*$

$* \mathrm{OH}+* \mathrm{OH} \rightarrow \mathrm{H}_{2} \mathrm{O} *+\mathrm{O} *$

$* \mathrm{CO}+\mathrm{O}^{*} \rightarrow \mathrm{CO}_{2} *+*$ 
The detailed energetics of all these steps will be discussed next. Notably, several of these steps describe the water-gas-shift reaction [55], which connect the final products of the selective (dehydrogenation) and unselective (dehydration) $\mathrm{HCOOH}$ decomposition routes.
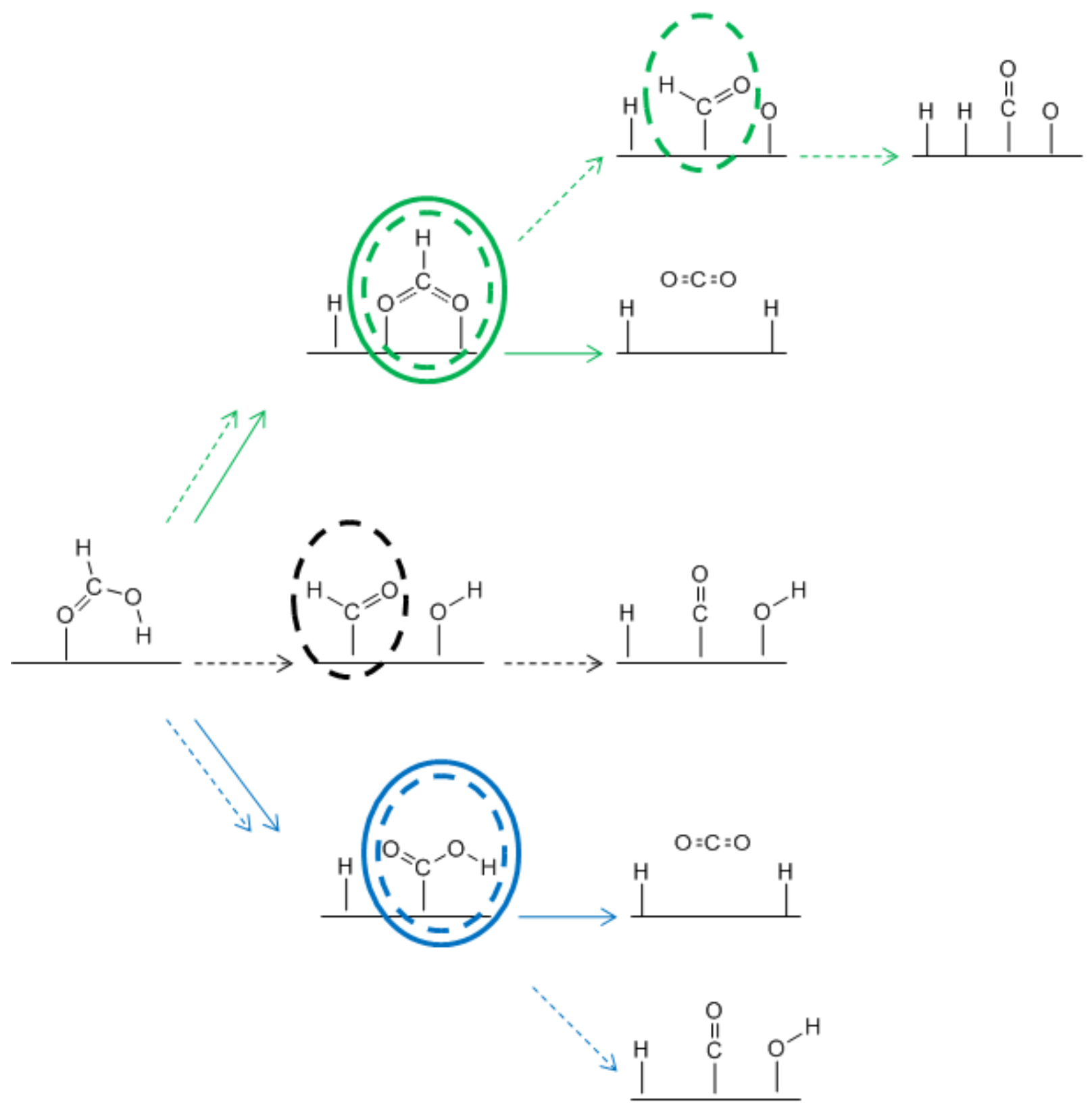

Scheme 1. Reaction network of steps studied for $\mathrm{HCOOH}$ decomposition on clean $\mathrm{Pd}(111)$. The green and blue arrows indicate $\mathrm{HCOO}$ and $\mathrm{COOH}$ routes, respectively. The black arrows represent the $\mathrm{HCOOH}$ dehydration pathway. The continuous and dashed arrows represent $\mathrm{CO}_{2}$ and $\mathrm{CO}$ formation, respectively. 


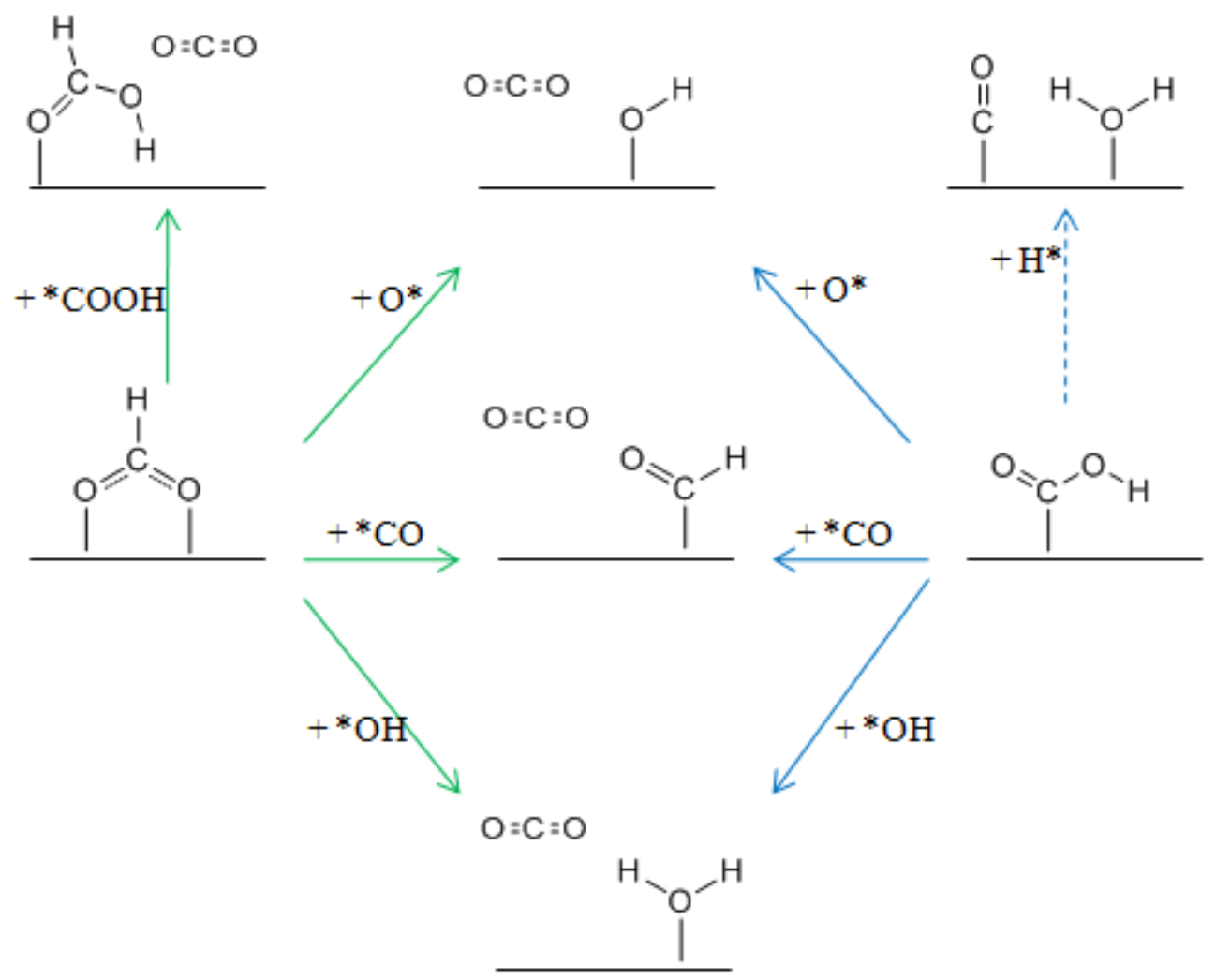

Scheme 2. Reaction network of steps for $\mathrm{HCOO}$ and $\mathrm{COOH}$ decomposition on $\mathrm{Pd}(111)$, in the presence of co-adsorbed species. The green and blue arrows indicate the $\mathrm{HCOO}$ and $\mathrm{COOH}$ routes, respectively. The continuous and dashed arrows represent $\mathrm{CO}_{2}$ and $\mathrm{CO}$ formation, respectively.

\subsection{Structures, binding energies and vibrational frequencies of reaction intermediates.}

The binding energies (BEs) of surface intermediates are reported in Table 1 along with the preferred adsorption sites, selected geometric parameters, the computed vibrational frequencies and the available experimental frequencies for $\mathrm{HCOOH}$ and $\mathrm{HCOO}$ [26].

The computed vibrational frequencies of $\mathrm{HCOOH}$ and $\mathrm{HCOO}$, see Table 1, agree reasonably well with those observed by Zheng et al. on $\operatorname{Pd}(111)[26]$. Although Zheng et al.[26] detected another frequency at $1630 \mathrm{~cm}^{-1}$ for adsorbed $\mathrm{HCOOH}$, Wang et al.[25] assigned an absorption band occurring at $\sim 1612 \mathrm{~cm}^{-1}$ to $\mathrm{H}_{2} \mathrm{O}$ adsorbed on the $\mathrm{Pd}$ surface. 
The calculated BEs are close to those reported by Ferrin et al.[56] and Herron et al.[50]. The $\mathrm{BE}$ of $\mathrm{HCOOH}$ is almost identical to that found by $\mathrm{Hu}$ et al.[34]. The BEs of $\mathrm{HCOO}$ and $\mathrm{COOH}$ are weaker with respect to those found by both Hu et al.[34] and Zhang et al.[37]. Finally, the BE of $\mathrm{CO}$ reproduces well the value reported by Zhang et al.[37] while it is stronger than the value from $\mathrm{Hu}$ et al.[34]. These differences may be explained by the different computational methodologies, e.g. functional and basis set, used in the calculations.

Table 1. Binding energy (BE), site preference, selected geometric parameters and vibrational frequencies $\left(>200 \mathrm{~cm}^{-1}\right)$ of $\mathrm{HCOOH}$ decomposition intermediates on $\mathrm{Pd}(111)$ surface $(\theta=1 / 9 \mathrm{ML})$.

\begin{tabular}{|c|c|c|c|c|c|c|c|}
\hline Species & Site & $\begin{array}{l}\mathrm{BE} \\
{[\mathrm{eV}]}\end{array}$ & $\begin{array}{l}\mathrm{X}-\mathrm{Pd} \\
{[\AA]}\end{array}$ & $\begin{array}{l}\mathrm{C}-\mathrm{O} \\
{[\AA]}\end{array}$ & $\begin{array}{l}\mathrm{O}-\mathrm{H} \\
{[\AA]}\end{array}$ & $\begin{array}{l}\mathrm{C}-\mathrm{H} \\
{[\AA]}\end{array}$ & Frequencies $\left[\mathrm{cm}^{-1}\right]$ \\
\hline $\mathrm{HCOOH}^{*}$ & $\begin{array}{l}\text { top- } \\
\text { bridge }\end{array}$ & -0.41 & $2.33^{\mathrm{a}}$ & $\begin{array}{l}1.24^{\mathrm{d}} ; \\
1.32^{\mathrm{e}}\end{array}$ & 1.02 & 1.10 & $\begin{array}{l}3041,2937,1691\left(1704^{f}\right), 1342, \\
1294\left(1243^{f}\right), 1142,988\left(947^{f}\right) \text {, } \\
668,643\end{array}$ \\
\hline $\mathrm{HCOO}^{*}$ & top-top & -2.34 & $2.18^{\mathrm{a}}$ & $\begin{array}{l}1.27 \\
1.27\end{array}$ & -- & 1.11 & $\begin{array}{l}2965\left(2904^{f}\right), 1558,1314 \\
\left(1342^{f}\right), 1303,973,736\left(792^{f}\right) \\
320,317,295\end{array}$ \\
\hline$* \mathrm{COOH}$ & top & -2.22 & $2.00^{\mathrm{b}}$ & $\begin{array}{l}1.24^{\mathrm{d}} ; \\
1.34^{\mathrm{e}}\end{array}$ & 0.99 & -- & $\begin{array}{l}3596,1653,1218,1130,671 \\
581,458,283,246\end{array}$ \\
\hline $\mathrm{CO}_{2} *$ & -- & -0.05 & -- & 1.18 & -- & -- & $2449,1348,622,615$ \\
\hline${ }^{*} \mathrm{CO}$ & $\mathrm{fcc}$ & -1.99 & $2.09^{\mathrm{b}}$ & 1.19 & -- & -- & $1868,311,299,298$ \\
\hline $\mathrm{HCO}^{*}$ & $\mathrm{fcc}$ & -2.26 & $2.11^{\mathrm{b}}$ & 1.26 & -- & 1.11 & $\begin{array}{l}2890,1478,1088,634,437, \\
263,254\end{array}$ \\
\hline$* \mathrm{OH}$ & $\mathrm{fcc}$ & -2.16 & $2.22^{\mathrm{a}}$ & -- & 0.98 & -- & $3790,353,352,334$ \\
\hline $\mathrm{H}_{2} \mathrm{O}^{*}$ & top & -0.31 & $2.45^{\mathrm{a}}$ & -- & 0.99 & -- & $3824,3717,1531,413,380$ \\
\hline $\mathrm{H}^{*}$ & fcc & -2.83 & $1.82^{\mathrm{c}}$ & -- & -- & -- & 988 \\
\hline $\mathrm{O}^{*}$ & fcc & -3.73 & $2.05^{\mathrm{a}}$ & -- & -- & -- & 444 \\
\hline
\end{tabular}

Table 1 indicates that $\mathrm{HCOOH}$ and $\mathrm{H}_{2} \mathrm{O}$ are weakly adsorbed, whereas $\mathrm{CO}_{2}$ is only physisorbed.

$\mathrm{HCOOH}$ is adsorbed nearly perpendicularly with the carbonyl oxygen bound to a top surface site and the hydroxyl group pointing towards a bridge site; HCOO interacts through its 
oxygen ends, in a top - top bidendate configuration; $\mathrm{COOH}$ is adsorbed through its carbon atom to a top site and its hydrogen atom pointing towards the surface. $\mathrm{H}_{2} \mathrm{O}$ and $\mathrm{OH}$ are adsorbed through the oxygen atom while $\mathrm{CO}$ and $\mathrm{HCO}$ are adsorbed through the carbon atom. $\mathrm{H}_{2} \mathrm{O}$ prefers adsorption to a top site while $\mathrm{H}, \mathrm{CO}, \mathrm{HCO}, \mathrm{O}$ and $\mathrm{OH}$ to an fcc site. The preferred adsorption modes for $\mathrm{HCOOH}, \mathrm{HCOO}$ and $\mathrm{COOH}$ are depicted in Figure 1; the calculated geometric parameters for adsorbed $\mathrm{HCOO}$ agree well with the experimental data obtained from LEED[26] and previous DFT computed values[26], as shown in Table 2.
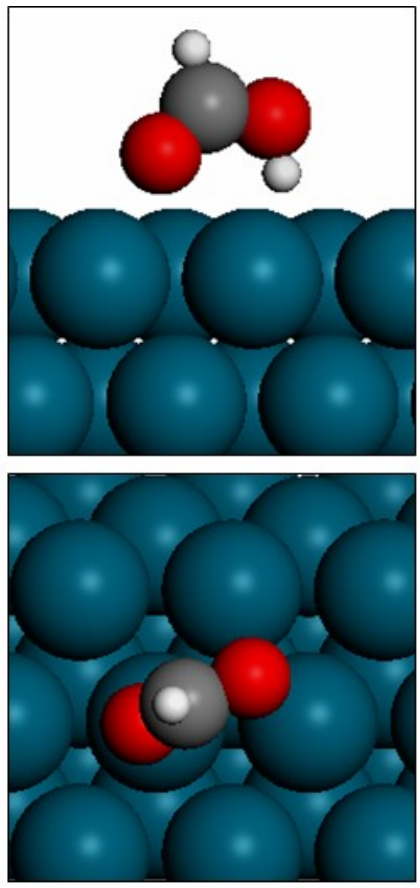

Formic acid $(\mathrm{HCOOH})$ $\mathrm{BE}=-0.41 \mathrm{eV}$
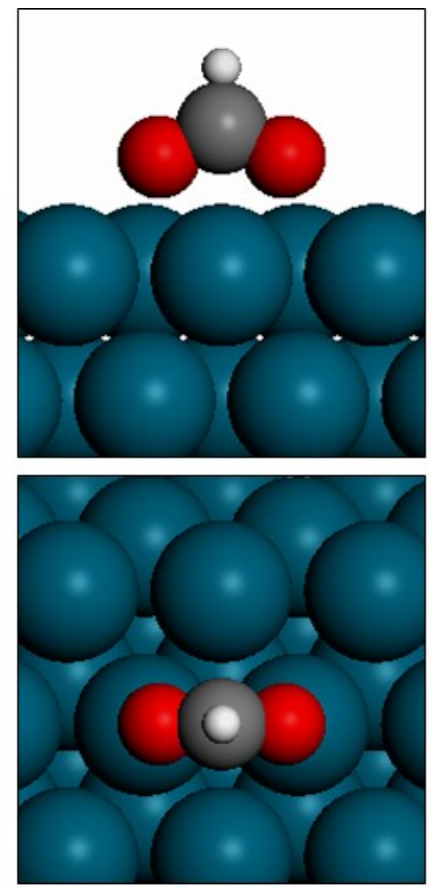

Formate intermediate ( $\mathrm{HCOO})$

$\mathrm{BE}=-2.34 \mathrm{eV}$
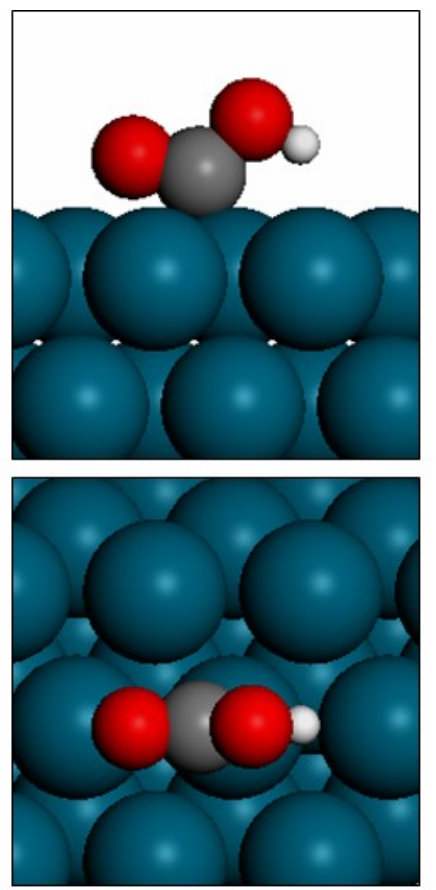

Carboxyl intermediate $(\mathrm{COOH})$

$\mathrm{BE}=-2.22 \mathrm{eV}$

Figure 1. Side and top views of the most stable configuration of $\mathrm{HCOOH}, \mathrm{HCOO}$ and $\mathrm{COOH}$ adsorbed on $\operatorname{Pd}(111)$ at $\theta=1 / 9 \mathrm{ML}$. Palladium, carbon, hydrogen and oxygen atoms are indicated with blue, dark grey, light grey and red spheres, respectively. 
Table 2. Calculated and experimental geometric parameters for HCOO adsorbed on $\operatorname{Pd}(111)^{\mathrm{a}}$.

\begin{tabular}{lll}
\hline Parameter & DFT & LEED[26] \\
\hline O-Pd & 2.18 & $2.16 \pm 0.06$ \\
O-C-O plane to the surface & 90 & $90 \pm 2$ \\
O-C-O & 130 & $130 \pm 5$ \\
C-O & 1.27 & $1.26 \pm 0.05$ \\
C-H & 1.11 & - \\
\hline
\end{tabular}

${ }^{\mathrm{a}}$ Bond length and bond angle are given in $\AA$ and ${ }^{\circ}$, respectively.

\subsection{Reaction barriers of elementary steps}

The calculated reaction energies and activation energy barriers for all the elementary steps studied are summarized in Table 3. To show the detailed energetic and geometric information of $\mathrm{HCOO}$ and $\mathrm{COOH}$ formation from $\mathrm{HCOOH}$, the reaction coordinate for step $1\left(\mathrm{HCOOH}^{*}+* \rightarrow\right.$ $\left.\mathrm{HCOO}^{*}+\mathrm{H}^{*}\right)$ and step $2\left(\mathrm{HCOOH}^{*}+* \rightarrow{ }^{*} \mathrm{COOH}+\mathrm{H}^{*}\right)$ are shown in Figures 2 and 3, respectively. For reaction $3\left(\mathrm{HCOO}^{*} \rightarrow \mathrm{CO}_{2}{ }^{*}+\mathrm{H}^{*}\right)$, two sequential steps are needed, (i.e. a rotation step followed by a bond-breaking step), and the reaction coordinates are shown in Figure 4. The transition state structures for step 4 and steps 6-10 are displayed in Figure 5; the reaction coordinates are reported in the Supporting Information (Figures S1-S6). Also for step 5 $\left(\mathrm{HCOOH}^{*}+* \rightarrow \mathrm{HCO}^{*}+* \mathrm{OH}\right)$, and step $11\left(\mathrm{HCOO}^{*}+* \mathrm{CO} \rightarrow \mathrm{HCO}^{*}+\mathrm{CO}_{2}^{*}\right)$, a sequence of two steps is needed, and the reaction coordinates are shown in Figures 6 and 7, respectively. Finally, the transition state structures for all the remaining steps (i.e. steps 12-20) are displayed in Figures 8 and 9; the reaction coordinates are reported in the Supporting Information (Figures S7-S15). 


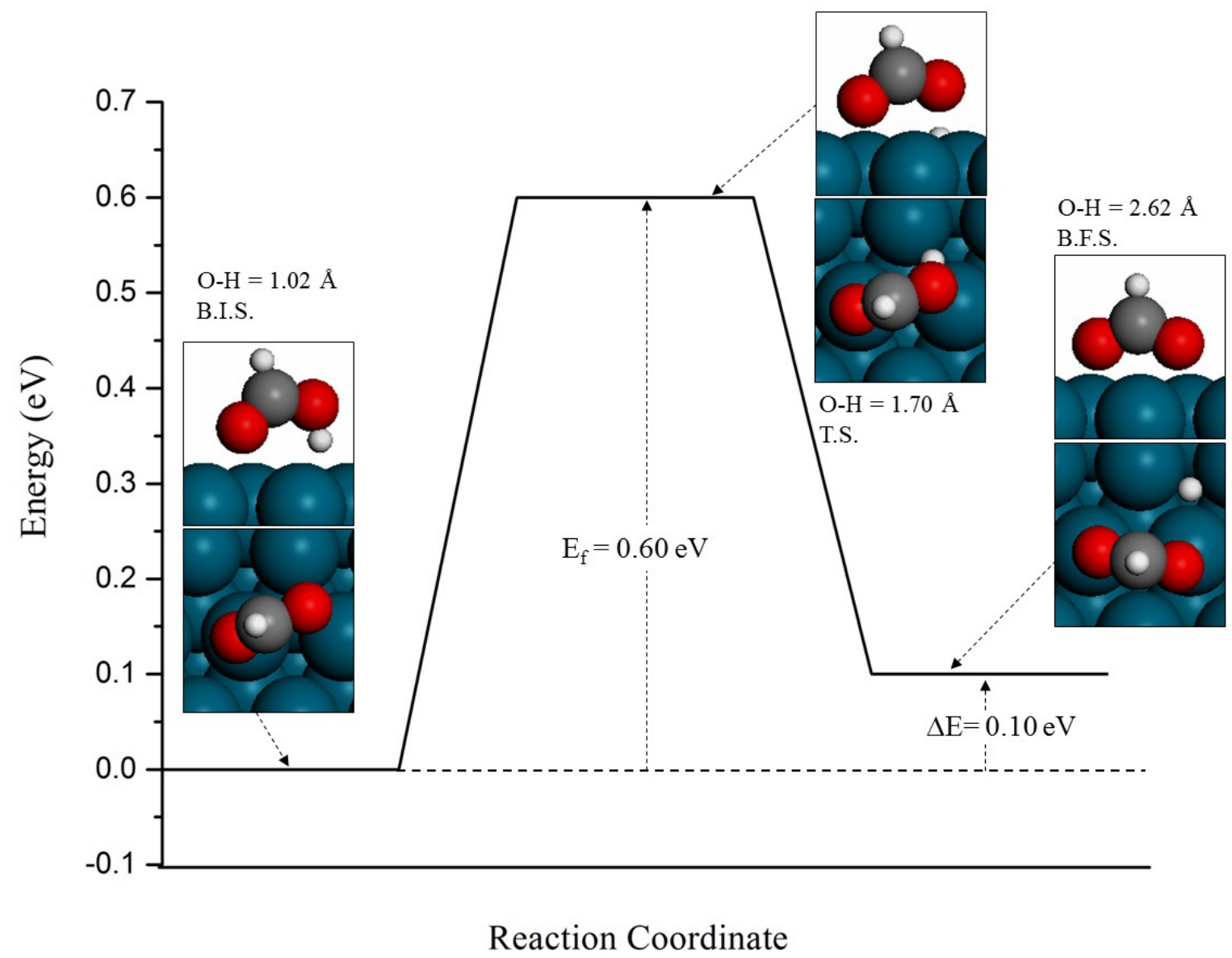

Figure 2. Reaction coordinate for step $1\left(\mathrm{HCOOH}^{*}+* \rightarrow \mathrm{HCOO}^{*}+\mathrm{H}^{*}\right)$ on $\mathrm{Pd}(111)$. Insets provide side and top views of B.I.S. (= best initial state), T.S. (= transition state) and B.F.S. (= best final state); the length of the bond being broken is indicated in each inset. $E_{f}$ and $\Delta \mathrm{E}$ denote the calculated activation energy barrier and reaction energy, respectively. Palladium, carbon, hydrogen and oxygen atoms are indicated in blue, dark grey, light grey and red, respectively. 


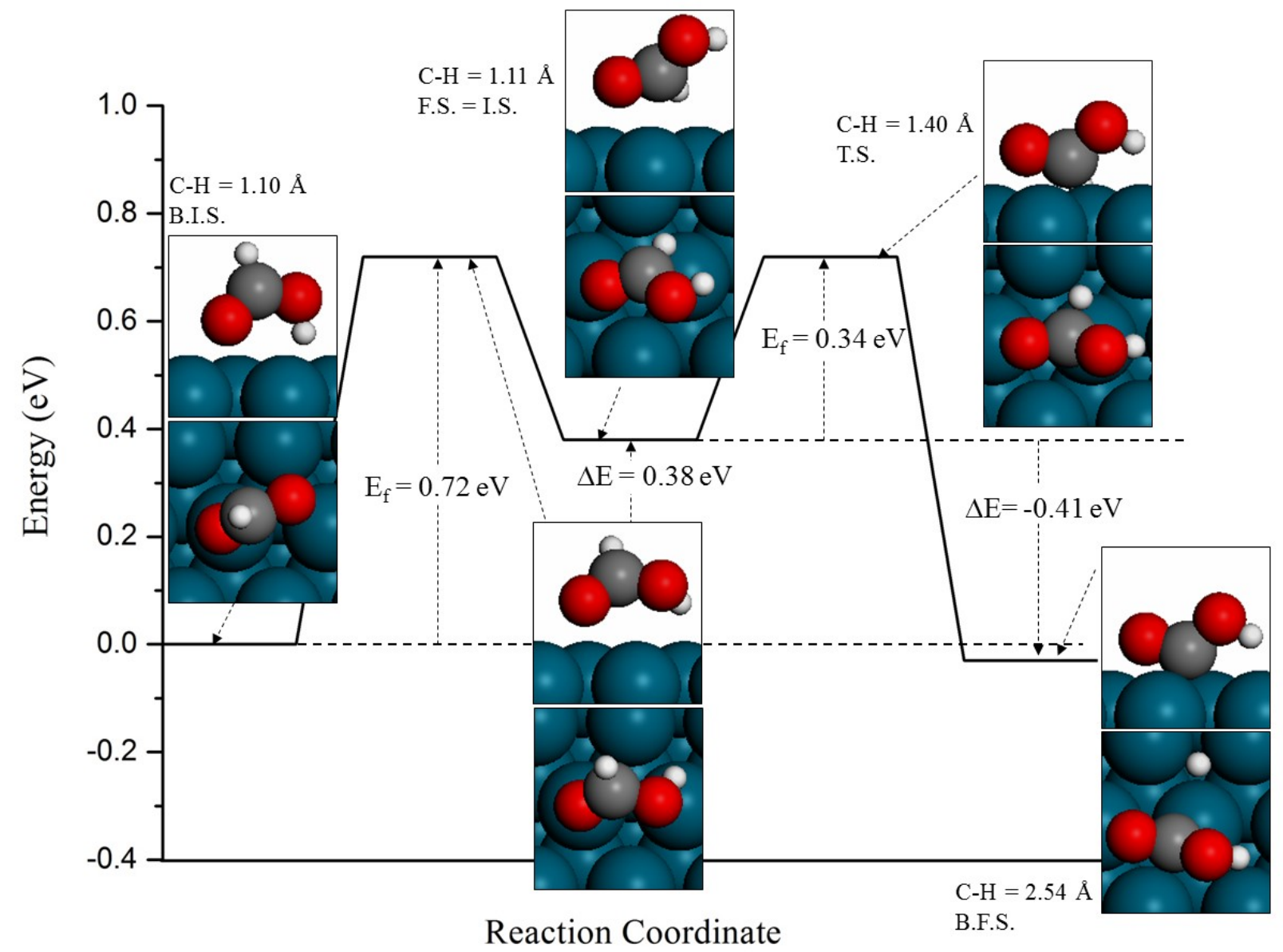

Figure 3. Reaction coordinate for step $2\left(\mathrm{HCOOH}^{*}+* \rightarrow * \mathrm{COOH}+\mathrm{H}^{*}\right)$ on $\mathrm{Pd}(111)$. Insets provide side and top views of B.I.S. (= best initial state), T.S. (= transition state), F.S. (= final state), I.S. (= initial state) and B.F.S. (= best final state); the length of the bond being broken is indicated in the inset. $\mathrm{E}_{\mathrm{f}}$ and $\Delta \mathrm{E}$ denote the calculated activation energy barrier and reaction energy, respectively. Palladium, carbon, hydrogen and oxygen atoms are indicated in blue, dark grey, light grey and red, respectively. 


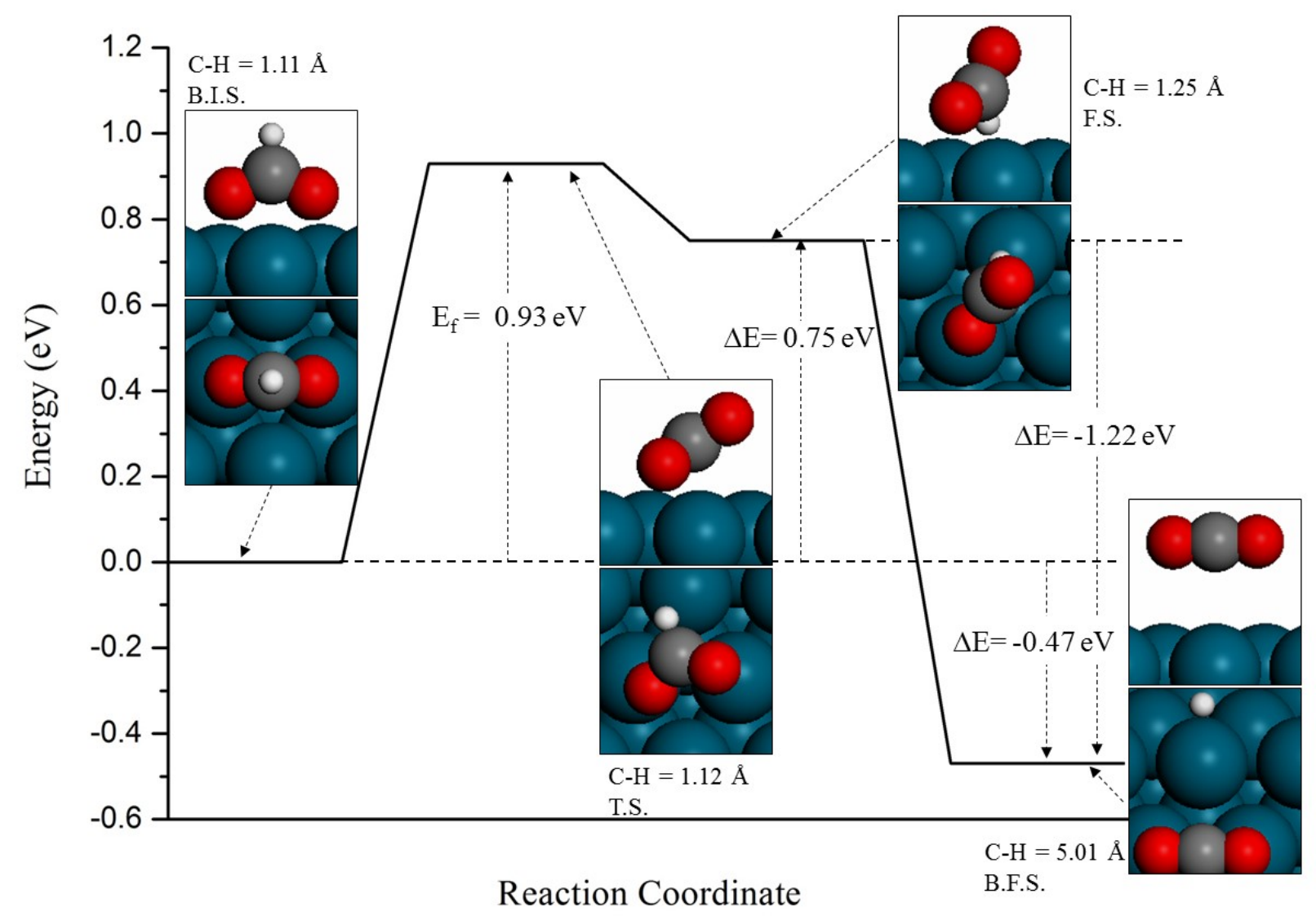

Figure 4. Reaction coordinate for step $3\left(\mathrm{HCOO}^{*} \rightarrow \mathrm{CO}_{2} *+\mathrm{H}^{*}\right)$ on $\mathrm{Pd}(111)$. Insets provide side and top views of B.I.S. (= best initial state), T.S. (= transition state), F.S. (= final state) and B.F.S. (= best final state); the length of the bond being broken is indicated in the inset. $\mathrm{E}_{\mathrm{f}}$ and $\Delta \mathrm{E}$ denote the calculated activation energy barrier and reaction energy, respectively. Palladium, carbon, hydrogen and oxygen atoms are indicated in blue, dark grey, light grey and red, respectively. 
$* \mathrm{COOH}+* \rightarrow \mathrm{CO}_{2}{ }^{*}+\mathrm{H}^{*}$
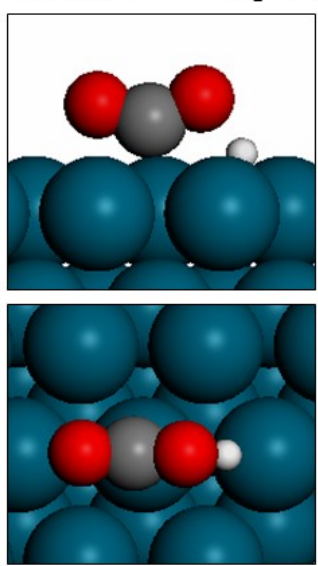

$\mathrm{O}-\mathrm{H}=1.55 \AA$

$* \mathrm{COOH}+* \rightarrow * \mathrm{CO}+* \mathrm{OH}$
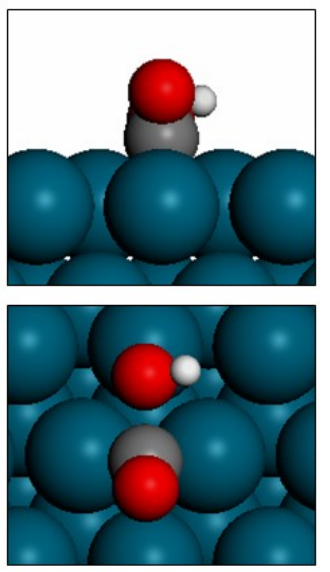

$\mathrm{C}-\mathrm{O}=1.97 \AA$
$\mathrm{HCOO}^{*}+* \rightarrow \mathrm{HCO}^{*}+\mathrm{O}^{*}$
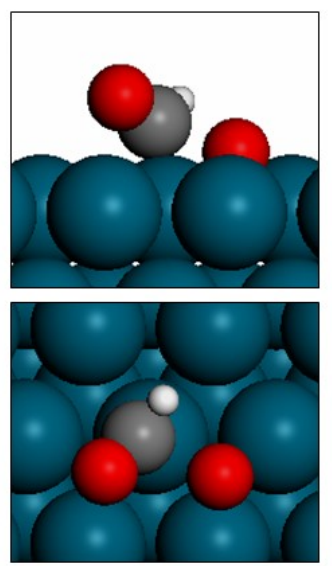

$\mathrm{C}-\mathrm{O}=2.15 \AA$

$\mathrm{HCOO}^{*}+\mathrm{O}^{*} \rightarrow \mathrm{CO}_{2} *+* \mathrm{OH}$
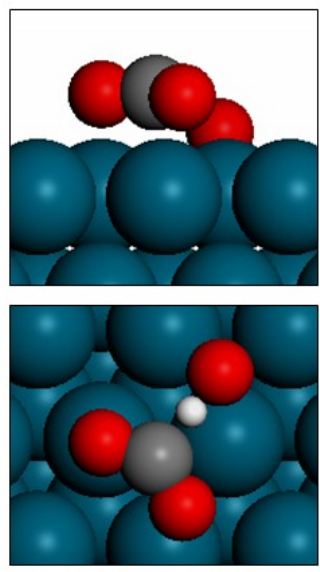

$\mathrm{C}-\mathrm{H}=1.32 \AA$
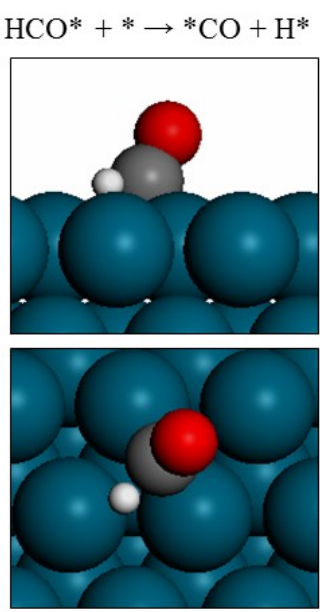

$\mathrm{C}-\mathrm{H}=1.24 \AA$

$\mathrm{HCOO}^{*}+* \mathrm{OH} \rightarrow \mathrm{CO}_{2}{ }^{*}+\mathrm{H}_{2} \mathrm{O} *$
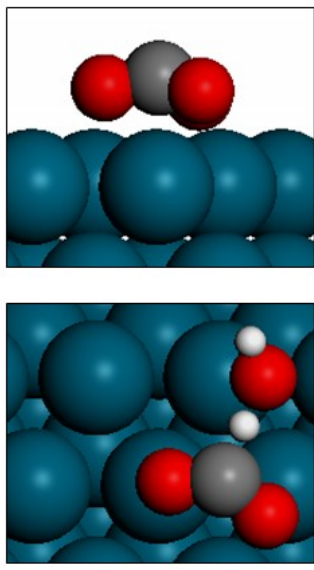

$\mathrm{C}-\mathrm{H}=1.30 \AA$

Figure 5. Side and top view of the transition state (T.S.) corresponding to Step $4\left({ }^{*} \mathrm{COOH}+* \rightarrow \mathrm{CO}_{2} *+\right.$ $\left.\mathrm{H}^{*}\right)$, Step $6\left(\mathrm{HCOO}^{*}+* \rightarrow \mathrm{HCO}^{*}+\mathrm{O}^{*}\right)$, Step $7\left(\mathrm{HCO}^{*}+* \rightarrow{ }^{*} \mathrm{CO}+\mathrm{H}^{*}\right)$, Step $8\left({ }^{*} \mathrm{COOH}+* \rightarrow{ }^{*} \mathrm{CO}\right.$ $\left.+\mathrm{OH}^{*}\right)$, Step $9\left(\mathrm{HCOO}^{*}+\mathrm{O}^{*} \rightarrow \mathrm{CO}_{2}{ }^{*}+{ }^{*} \mathrm{OH}\right)$ and Step $10\left(\mathrm{HCOO}^{*}+{ }^{*} \mathrm{OH} \rightarrow \mathrm{CO}_{2}{ }^{*}+\mathrm{H}_{2} \mathrm{O}^{*}\right)$ on $\operatorname{Pd}(111)$. The length of the bond being broken is indicated. Palladium, carbon, hydrogen and oxygen atoms are indicated in blue, dark grey, light grey and red, respectively. 


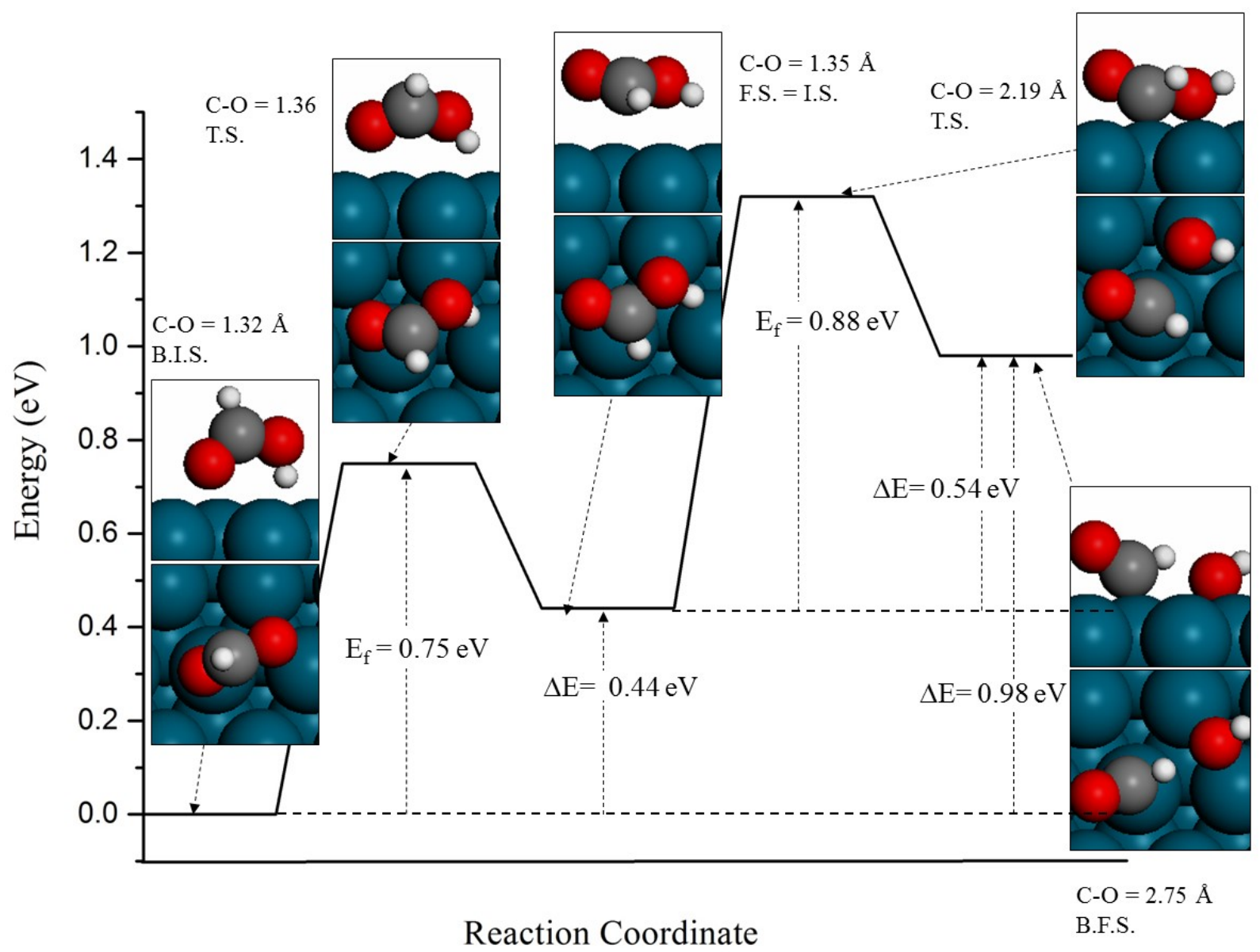

Figure 6. Reaction coordinate for step $5\left(\mathrm{HCOOH}^{*}+* \rightarrow \mathrm{HCO}^{*}+* \mathrm{OH}\right)$ on $\mathrm{Pd}(111)$. Insets provide side and top views of B.I.S. (= best initial state), T.S. (= transition state), F.S. (= final state), I.S. (= initial state) and B.F.S. (= best final state); the length of the bond being broken is indicated in the inset. $\mathrm{E}_{\mathrm{f}}$ and $\Delta \mathrm{E}$ denote the calculated activation energy barrier and reaction energy, respectively. Palladium, carbon, hydrogen and oxygen atoms are indicated in blue, dark grey, light grey and red, respectively. 


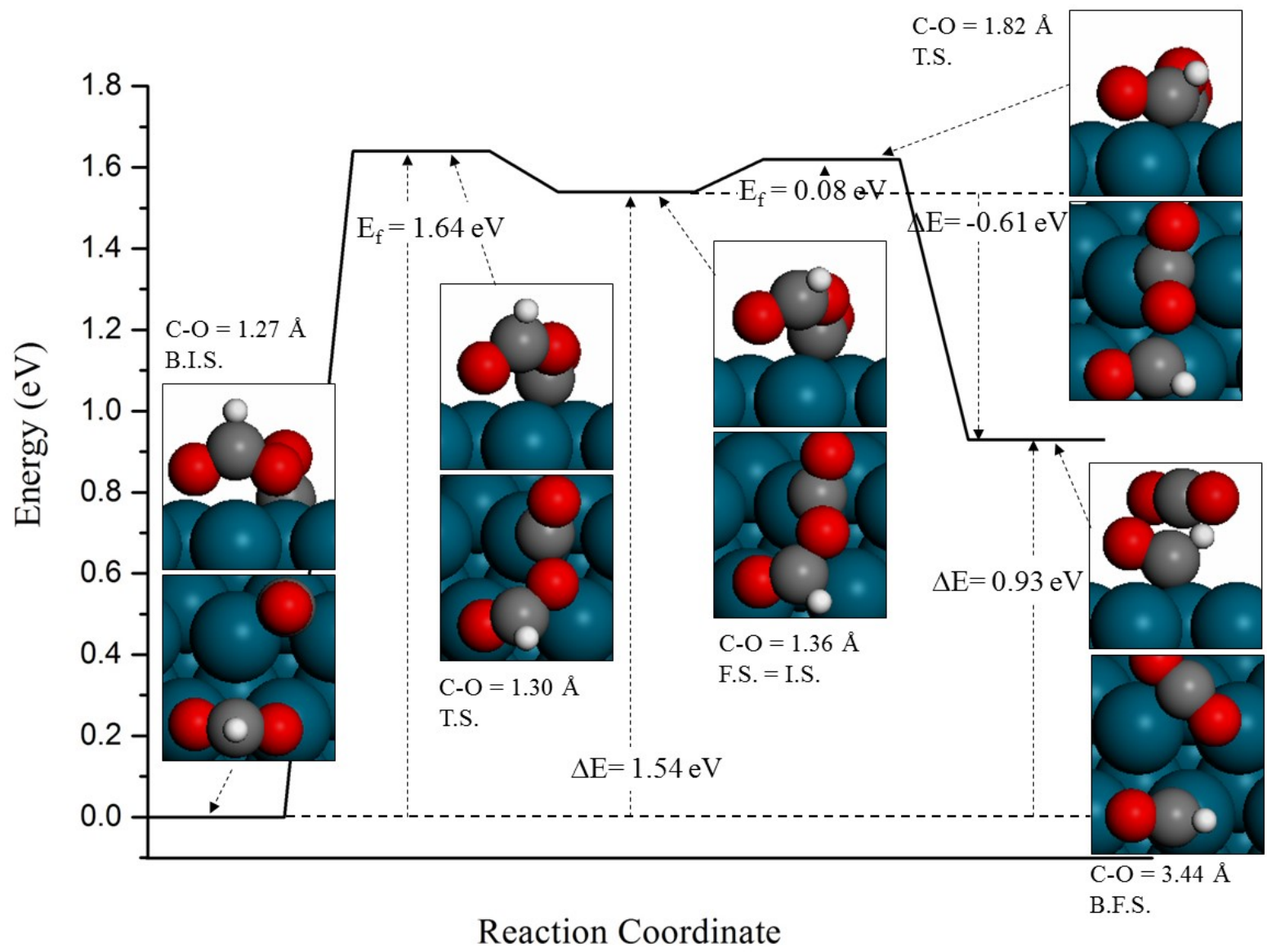

Figure 7. Reaction coordinate for step $11\left(\mathrm{HCOO}^{*}+* \mathrm{CO} \rightarrow \mathrm{HCO}^{*}+\mathrm{CO}_{2}\right)$ on $\mathrm{Pd}(111)$. Insets provide side and top views of B.I.S. (= best initial state), T.S. (= transition state), F.S. (= final state), I.S. (= initial state) and B.F.S. (= best final state); the length of the bond being broken is indicated in the inset. $\mathrm{E}_{\mathrm{f}}$ and $\Delta \mathrm{E}$ denote the calculated activation energy barrier and reaction energy, respectively. Palladium, carbon, hydrogen and oxygen atoms are indicated in blue, dark grey, light grey and red, respectively. 
$\mathrm{HCOO}^{*}+* \mathrm{COOH} \rightarrow+\mathrm{HCOOH}^{*}+\mathrm{CO}_{2} *$
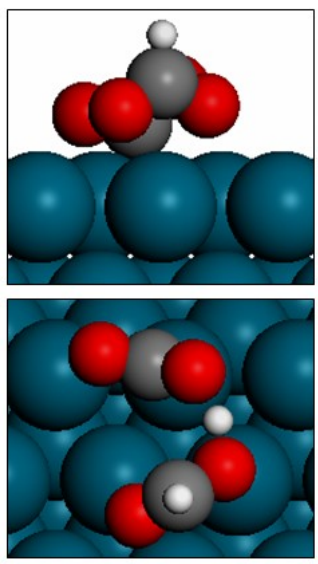

$\mathrm{O}-\mathrm{H}=1.29 \AA$

$* \mathrm{COOH}+\mathrm{H}^{*} \rightarrow * \mathrm{CO}+\mathrm{H}_{2} \mathrm{O} *$
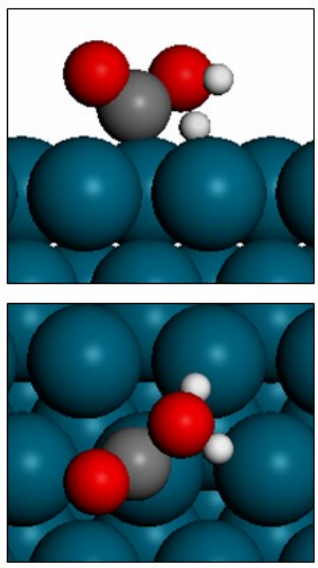

$\mathrm{C}-\mathrm{O}=1.52 \AA$
$* \mathrm{COOH}+\mathrm{O}^{*} \rightarrow \mathrm{CO}_{2}^{*}+* \mathrm{OH}$
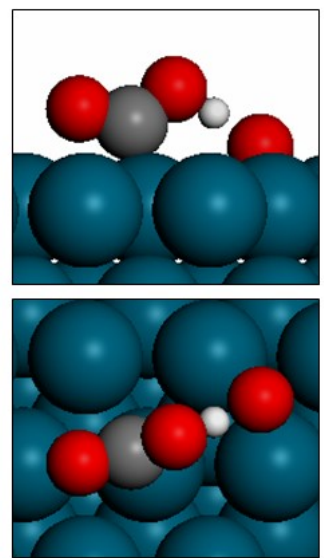

$\mathrm{O}-\mathrm{H}=1.10 \AA$

$* \mathrm{COOH}+* \mathrm{CO} \rightarrow \mathrm{CO}_{2} *+\mathrm{HCO}^{*}$
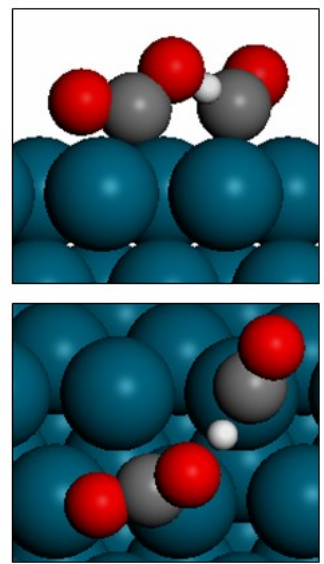

$\mathrm{O}-\mathrm{H}=1.27 \AA$

Figure 8. Side and top view of the transition state (T.S.) corresponding to Step 12 (HCOO* $+* \mathrm{COOH} \rightarrow$ $\mathrm{HCOOH}^{*}+\mathrm{CO}_{2} *$ ), Step $13\left({ }^{*} \mathrm{COOH}+\mathrm{O}^{*} \rightarrow \mathrm{CO}_{2}{ }^{*}+* \mathrm{OH}\right)$, Step $15\left(* \mathrm{COOH}+\mathrm{H}^{*} \rightarrow{ }^{*} \mathrm{CO}+\mathrm{H}_{2} \mathrm{O}^{*}\right)$ and Step $16\left({ }^{*} \mathrm{COOH}+{ }^{*} \mathrm{CO} \rightarrow \mathrm{CO}_{2}{ }^{*}+\mathrm{HCO}^{*}\right)$ on $\mathrm{Pd}(111)$. The length of the bond being broken is indicated. $\mathrm{H}$ being involved in the transfer is indicated for Step 12. Palladium, carbon, hydrogen and oxygen atoms are indicated in blue, dark grey, light grey and red, respectively. 


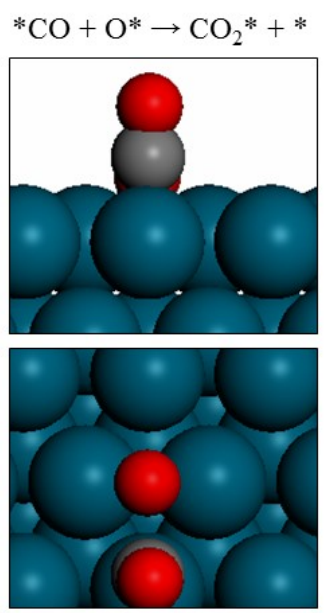

$\mathrm{C}-\mathrm{O}=2.15 \AA$

$* \mathrm{OH}+* \mathrm{OH} \rightarrow \mathrm{H}_{2} \mathrm{O} *+\mathrm{O} *$
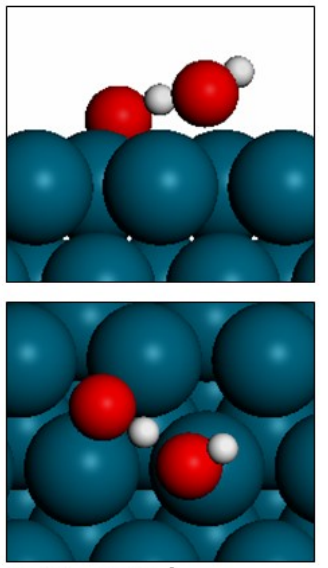

$\mathrm{O}-\mathrm{H}=1.17 \AA$
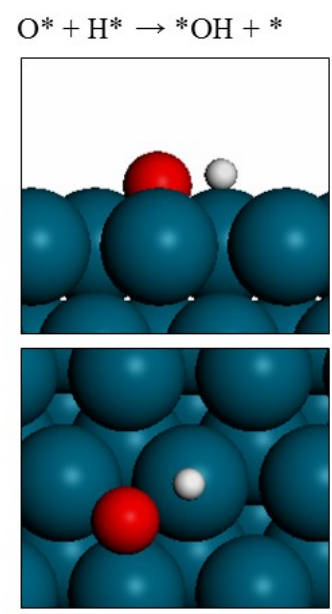

$\mathrm{O}-\mathrm{H}=1.64 \AA$

$$
\mathrm{H}^{*}+* \mathrm{OH} \rightarrow \mathrm{H}_{2} \mathrm{O}^{*}
$$
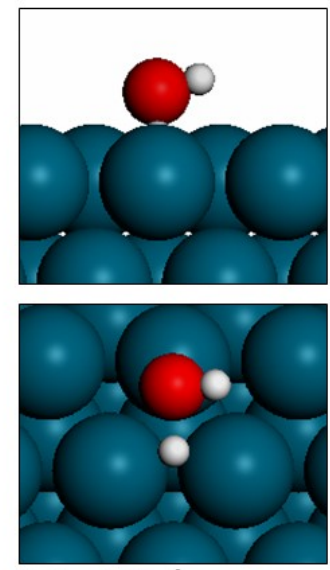

$\mathrm{O}-\mathrm{H}=1.75 \AA$

Figure 9. Side and top view of the transition state (T.S.) corresponding to Step $17\left({ }^{*} \mathrm{CO}+\mathrm{O}^{*} \rightarrow \mathrm{CO}_{2} *+\right.$ $\left.{ }^{*}\right)$, Step $18\left(\mathrm{O}^{*}+\mathrm{H}^{*} \rightarrow{ }^{*} \mathrm{OH}+*\right)$, Step $19\left(* \mathrm{OH}+{ }^{*} \mathrm{OH} \rightarrow \mathrm{H}_{2} \mathrm{O}^{*}+\mathrm{O}^{*}\right)$ and Step $20\left(\mathrm{H}^{*}+* \mathrm{OH} \rightarrow\right.$ $\left.\mathrm{H}_{2} \mathrm{O}^{*}+{ }^{*}\right)$ on $\mathrm{Pd}(111)$. The length of the bond being formed or broken is indicated. Palladium, carbon, hydrogen and oxygen atoms are indicated in blue, dark grey, light grey and red, respectively.

Table 3. Reaction energy $(\Delta \mathrm{E})$, activation energy barrier $\left(\mathrm{E}_{\mathrm{f}}\right)$ for all elementary steps on $\operatorname{Pd}(111)$.

\begin{tabular}{lll}
\hline Elementary step & $\Delta \mathrm{E}^{\mathrm{a}}$ & $\mathrm{E}_{\mathrm{f}}{ }^{\mathrm{b}}$ \\
\hline$(1) \mathrm{HCOOH}^{*}+* \rightarrow \mathrm{HCOO}^{*}+\mathrm{H}^{*}$ & 0.10 & 0.60 \\
$(2) \mathrm{HCOOH}^{*}+* \rightarrow * \mathrm{COOH}+\mathrm{H}^{*}$ & -0.03 & $0.34+0.38$
\end{tabular}




\begin{tabular}{|c|c|c|}
\hline (3) $\mathrm{HCOO}^{*}+* \rightarrow \mathrm{CO}_{2}^{*}+\mathrm{H}^{*}$ & -0.47 & 0.93 \\
\hline (4) $* \mathrm{COOH}+* \rightarrow \mathrm{CO}_{2} *+\mathrm{H}^{*}$ & -0.32 & 0.70 \\
\hline (5) $\mathrm{HCOOH}^{*}+* \rightarrow \mathrm{HCO}^{*}+* \mathrm{OH}$ & 0.98 & $0.88+0.44$ \\
\hline (6) $\mathrm{HCOO}^{*}+* \rightarrow \mathrm{HCO}^{*}+\mathrm{O}^{*}$ & 1.40 & 1.95 \\
\hline (7) $\mathrm{HCO}^{*}+* \rightarrow * \mathrm{CO}+\mathrm{H}^{*}$ & -1.16 & 0.14 \\
\hline$(8) * \mathrm{COOH}+* \rightarrow * \mathrm{CO}+\mathrm{OH}^{*}$ & -0.07 & 0.80 \\
\hline (9) $\mathrm{HCOO}^{*}+\mathrm{O}^{*} \rightarrow \mathrm{CO}_{2} *+* \mathrm{OH}$ & -0.66 & $1.46^{\mathrm{c}}$ \\
\hline (10) $\mathrm{HCOO}^{*}+* \mathrm{OH} \rightarrow \mathrm{CO}_{2} *+\mathrm{H}_{2} \mathrm{O}^{*}$ & -1.09 & $1.22+0.24$ \\
\hline (11) $\mathrm{HCOO}^{*}+* \mathrm{CO} \rightarrow \mathrm{CO}_{2} *+\mathrm{HCO}^{*}$ & 0.93 & $1.54+0.08$ \\
\hline (12) $\mathrm{HCOO}^{*}+* \mathrm{COOH} \rightarrow \mathrm{HCOOH}^{*}+\mathrm{CO}_{2} *$ & 0.28 & 0.39 \\
\hline$(13) * \mathrm{COOH}+\mathrm{O}^{*} \rightarrow \mathrm{CO}_{2} *+* \mathrm{OH}$ & -0.35 & 0.05 \\
\hline$(14) * \mathrm{COOH}+* \mathrm{OH} \rightarrow \mathrm{CO}_{2} *+\mathrm{H}_{2} \mathrm{O} *$ & $-0.63-0.22$ & 0.00 \\
\hline$(15) * \mathrm{COOH}+\mathrm{H}^{*} \rightarrow * \mathrm{CO}+\mathrm{H}_{2} \mathrm{O} *$ & -0.83 & 1.20 \\
\hline$(16) * \mathrm{COOH}+* \mathrm{CO} \rightarrow \mathrm{CO}_{2} *+\mathrm{HCO}^{*}$ & 1.24 & 1.52 \\
\hline$(17) * \mathrm{CO}+\mathrm{O}^{*} \rightarrow \mathrm{CO}_{2} *+*$ & -0.52 & 1.40 \\
\hline (18) $\mathrm{O}^{*}+\mathrm{H}^{*} \rightarrow * \mathrm{OH}+*$ & -0.30 & 1.12 \\
\hline$(19) * \mathrm{OH}+* \mathrm{OH} \rightarrow \mathrm{H}_{2} \mathrm{O} *+\mathrm{O}^{*}$ & -0.30 & 0.03 \\
\hline (20) $\mathrm{H}^{*}+* \mathrm{OH} \rightarrow \mathrm{H}_{2} \mathrm{O}^{*}+*$ & -0.51 & 0.63 \\
\hline (21) $\mathrm{H}^{*}+\mathrm{H}^{*} \rightarrow \mathrm{H}_{2}+2^{*}$ & $1.09^{\mathrm{d}}$ & $1.09^{\mathrm{d}}$ \\
\hline
\end{tabular}

${ }^{\mathrm{a}}$ If the final state (F.S.) is not the best final state (B.F.S), then $\Delta \mathrm{E}$ is reported as $\Delta \mathrm{E}(\mathrm{NEB})-$ (F.S. B.F.S.)

${ }^{b}$ If the initial state (I.S.) is not the best initial state (B.I.S.), then $E_{f}$ is reported a $E_{f}(N E B)+$ (I.S. - B.I.S.)

${ }^{c}$ The path was discretized by a total of eleven images.

${ }^{\mathrm{d}} \Delta \mathrm{E}$ and $\mathrm{E}_{\mathrm{f}}$ were computed from the two adsorbed $\mathrm{H}$ atoms at infinite separation since $\mathrm{H}_{2}$ dissociation on $\operatorname{Pd}(111)$ is found to be a nearly spontaneous process[57].

\subsubsection{HCOOH decomposition on the clean Pd(111) surface}

$\boldsymbol{H C O O H}^{*}+* \rightarrow \boldsymbol{H C O O}^{*}+\boldsymbol{H}^{*}$ (Step 1). This step, which starts from $\mathrm{HCOOH}$ adsorbed in the most stable perpendicular trans- configuration, is slightly endothermic $(\sim 0.10 \mathrm{eV})$ and requires an activation energy of $0.60 \mathrm{eV}$ (Figure 2). The $\mathrm{O}-\mathrm{H}$ distance increases from $1.02 \AA$ (B.I.S) to $2.62 \AA$ (B.F.S.) and is equal to $1.70 \AA$ at the T.S.. The final co-adsorbed state, with 
HCOO (top-top) and $\mathrm{H}$ (fcc), includes a destabilization of $\sim 0.2 \mathrm{eV}$ with respect to the coadsorption at infinite separation.

$\boldsymbol{H C O O H}^{*+} * \rightarrow{ }^{*} \boldsymbol{C O O H}+\boldsymbol{H}^{*}$ (Step 2). Before decomposing to carboxyl, adsorbed $\mathrm{HCOOH}$ reorients from the perpendicular trans- configuration to a nearly parallel cisconfiguration (Figure 3). This re-orientation needs an activation energy of $0.72 \mathrm{eV}$. The subsequent $\mathrm{C}-\mathrm{H}$ bond scission, which is characterized by an increase of the corresponding distance by $0.29 \AA$ (I.S. $\rightarrow$ T.S.) and $1.14 \AA$ (T.S. $\rightarrow$ B.F.S) is exothermic by $0.41 \mathrm{eV}$ and has an activation energy barrier of $0.34 \mathrm{eV}$. A destabilization of $0.2 \mathrm{eV}$ with respect to the co-adsorption at infinite separation is attributed to the interaction between co-adsorbed $\mathrm{COOH}$ (top) and $\mathrm{H}$ (fcc).

$\mathrm{HCOO}^{*}+* \rightarrow \mathrm{CO}_{2} *+\mathrm{H}^{*}$ (Step 3). Before formate's decomposition, one O-Pd bond is broken, which leads to the formation of a monodendate HCOO: the activation energy barrier associated to this process is $0.93 \mathrm{eV}$ (Figure 4). The C-H bond length changes from $1.11 \AA$ (B.I.S) to $1.12 \AA$ (T.S.) up to 1.25 (F.S.). The subsequent C-H bond scission is a spontaneous process. The overall step is exothermic by $0.47 \mathrm{eV}$. The final $\mathrm{CO}_{2}$ (almost desorbed) and $\mathrm{H}$ (fcc) are co-adsorbed with negligible interaction.

${ }^{*} \mathrm{COOH}+* \rightarrow \mathrm{CO}_{2} *+\mathrm{H}^{*}$ (Step 4). The dehydrogenation of $\mathrm{COOH}$ requires an activation energy of $0.70 \mathrm{eV}$ and is exothermic by $0.32 \mathrm{eV}$ (Figure S1). The $\mathrm{O}-\mathrm{H}$ distance (Figure 5) changes from $0.99 \AA$ (B.I.S.) to $3.66 \AA$ (B.F.S.) through a value of $1.55 \AA$ (T.S.). The final $\mathrm{CO}_{2}$ (almost desorbed) and $\mathrm{H}(\mathrm{fcc})$ are co-adsorbed with no interaction energy.

$\mathrm{HCOOH}^{*}+* \rightarrow \mathrm{HCO}^{*}+{ }^{*} \mathrm{OH}$ (Step 5). Before decomposing, HCOOH transforms itself from the perpendicular adsorbed configuration to a nearly parallel configuration having a substantially smaller binding energy (Figure 6). This step has an activation energy barrier of 0.75 
$\mathrm{eV}$. The subsequent $\mathrm{C}-\mathrm{O}$ bond scission which is characterized by an increase of the corresponding distance of $0.84 \AA$ (I.S. $\rightarrow$ T.S.) and $0.56 \AA$ (T.S. $\rightarrow$ B.F.S.) is endothermic by $0.54 \mathrm{eV}$ and requires an activation energy of $0.88 \mathrm{eV}$. The final co-adsorbed $\mathrm{HCO}$ (top) and $\mathrm{OH}$ (fcc/bridge) have no interaction energy.

$\boldsymbol{H C O O}^{*}+* \rightarrow \boldsymbol{H C O} *+\boldsymbol{O} *($ Step 6). This step is endothermic by $1.40 \mathrm{eV}$ and needs an activation energy of $1.95 \mathrm{eV}$ (Figure S2). The C-O distance (Figure 5) increases from $1.27 \AA$ (B.I.S) to $3.18 \AA$ (B.F.S) and has a value of $2.15 \AA$ at the T.S. The co-adsorption of HCO (fcc/bridge) and $\mathrm{O}(\mathrm{fcc})$ is repulsive by about $0.1 \mathrm{eV}$ with respect to the co-adsorption at infinite separation.

$\boldsymbol{H C O} *+* \rightarrow * \boldsymbol{C O}+\boldsymbol{H}^{*}(\boldsymbol{S t e p} 7)$. The decomposition of HCO is exothermic by $1.16 \mathrm{eV}$ and requires an activation energy of $0.14 \mathrm{eV}$ (Figure S3). The $\mathrm{C}-\mathrm{H}$ distance (Figure 5) changes from $1.11 \AA$ (B.I.S.) to $1.24 \AA$ (T.S.) up to $2.96 \AA$ (B.F.S). In the co-adsorbed state, $\mathrm{CO}$ (fcc) and $\mathrm{H}$ (fcc) destabilize each other by $\sim 0.1 \mathrm{eV}$ with respect to co-adsorption at infinite separation.

$* \mathbf{C O O H}+* \rightarrow{ }^{*} \boldsymbol{C O}+* \boldsymbol{O H}($ Step 8). This step is slightly exothermic by $0.07 \mathrm{eV}$ and has an activation energy barrier of $0.80 \mathrm{eV}$ (Figure S4). The C-O distance (Figure 5) increases by $0.63 \AA$ (B.I.S. $\rightarrow$ T.S.) and $1.47 \AA$ (T.S. $\rightarrow$ B.F.S.). The co-adsorption of CO (fcc) and OH (fcc/bridge) leads to a small stabilization with respect to co-adsorption at infinite separation.

\subsubsection{HCOO and COOH decomposition in the presence of co-adsorbed species}

$$
\mathrm{HCOO}^{*}+\boldsymbol{O}^{*} \rightarrow \mathrm{CO}_{2} *+* \boldsymbol{O H} \text { (Step 9). Co-adsorbed HCOO (top-top) and O (fec) do not }
$$
interact with each other. The $\mathrm{C}-\mathrm{H}$ bond scission (Figure 5), with the corresponding distance changing from $1.11 \AA$ (B.I.S.) to $1.32 \AA$ (T.S.) up to $3.82 \AA$ (B.F.S.), is exothermic by $0.66 \mathrm{eV}$ 
and requires an activation energy of $1.46 \mathrm{eV}$ (Figure S5). The final state involves $\mathrm{CO}_{2}($ almost desorbed) and $\mathrm{OH}$ (fcc), which do not interact with each other.

$\mathrm{HCOO}^{*}+* \mathrm{OH} \rightarrow \mathrm{CO}_{2} *+\mathrm{H}_{2} \mathrm{O} *($ Step 10). The initial state for the elementary step involves the co-adsorption of $\mathrm{HCOO}$ (top-top) and $\mathrm{OH}$ (bridge) with no interaction energy. However, this configuration is $0.24 \mathrm{eV}$ less stable than the best one on the surface. The following $\mathrm{C}-\mathrm{H}$ bond scission (Figure 5) has an activation energy barrier of $1.22 \mathrm{eV}$ and is exothermic by $1.09 \mathrm{eV}$ (Figure S6). The C-H distance changes from 1.10 А̊ (I.S.) to $3.09 \AA \AA$ (B.F.S.) and is equal to $1.30 \AA$ at the T.S. The final co-adsorbed state has $\mathrm{CO}_{2}$ (almost desorbed) and $\mathrm{H}_{2} \mathrm{O}$ (top), stabilizing each other by $\sim 0.1 \mathrm{eV}$.

$\mathrm{HCOO}^{*}+\mathrm{CO}^{*} \rightarrow \mathrm{CO}_{2}^{*}+\mathrm{HCO}^{*}($ Step 11). Before $\mathrm{C}-\mathrm{H}$ bond scission starts, a stable complex HCOOCO is formed: the activation energy barrier for O-C bond formation is $1.64 \mathrm{eV}$ (Figure 7). The decomposition of that complex into $\mathrm{CO}_{2}$ and $\mathrm{HCO}$ requires an activation energy of $0.08 \mathrm{eV}$ and leads to an increase of the C-O distance by $0.46 \AA$ (I.S. $\rightarrow$ T.S.) and $1.62 \AA$ (T.S. $\rightarrow$ B.F.S.). The overall process is endothermic by $0.93 \mathrm{eV}$. The final state involves $\mathrm{CO}_{2}($ almost desorbed) and HCO (top), which repel each other by $\sim 0.1 \mathrm{eV}$.

$\mathrm{HCOO} *+* \mathrm{COO} \underline{\mathrm{H}} \rightarrow \mathrm{HCOO} \underline{\mathrm{H}} *+\mathrm{CO}_{2} *($ Step 12). The co-adsorption of HCOO (toptop) and $\mathrm{COOH}$ (top) is characterized by a slight destabilization with respect to the co-adsorption at infinite separation. The $\mathrm{H}$ transfer from $\mathrm{COOH}$ to $\mathrm{HCOO}$ (indicated by the underscore) is endothermic by $0.28 \mathrm{eV}$ and needs an activation energy of $0.39 \mathrm{eV}$ (Figure S7). The O-H distance (Figure 8) in $\mathrm{COOH}$ is equal to $0.99 \AA$ (B.I.S.), $1.29 \AA$ (T.S.) and $2.88 \AA$ (B.F.S.) The final $\mathrm{CO}_{2}$ (top) and $\mathrm{HCOOH}$ (top-top) are co-adsorbed with a destabilization of about $0.15 \mathrm{eV}$ with respect to their co-adsorption at infinite separation. 
$* \mathrm{COOH}+\boldsymbol{O} * \rightarrow \mathrm{CO}_{2} *+* \boldsymbol{O H}$ (Step 13). The co-adsorption of COOH (top) and O (fcc) is characterized by a stabilization of about $0.1 \mathrm{eV}$ with respect to co-adsorption at infinite separation: the interaction between the two intermediates leads to a weakening of the COO-H bond. The subsequent $\mathrm{O}-\mathrm{H}$ bond scission is exothermic by $0.35 \mathrm{eV}$ and is a nearly spontaneous process requiring an activation energy of $0.05 \mathrm{eV}$ (Figure S8). The $\mathrm{O}-\mathrm{H}$ distance (Figure 8) increases by $0.09 \AA$ (B.I.S. $\rightarrow$ T.S.) and $0.71 \AA$ (T.S. $\rightarrow$ B.F.S.). The final $\mathrm{CO}_{2}$ (top) and $\mathrm{OH}$ (fcc) are co-adsorbed with no interaction energy.

$* \mathrm{COOH}+* \mathrm{OH} \rightarrow \mathrm{CO}_{2} *+\mathrm{H}_{2} \mathrm{O} *($ Step 14). The co-adsorption of $\mathrm{COOH}$ (top) and $\mathrm{OH}$ (fcc) leads to a stabilization of about $0.1 \mathrm{eV}$ with respect to their co-adsorption at infinite separation. The $\mathrm{O}-\mathrm{H}$ bond scission is exothermic by $0.63 \mathrm{eV}$ and is spontaneous with an increase of the corresponding distance by $0.60 \AA$ (Figure S9). The final state, has $\mathrm{CO}_{2}$ (top) and $\mathrm{H}_{2} \mathrm{O}$ (bridge) co-adsorbed, but we could find a more stable co-adsorbed state (by $0.22 \mathrm{eV}$ ).

$* \mathrm{COOH}+\mathrm{H}^{*} \rightarrow \mathrm{CO} *+\mathrm{H}_{2} \mathrm{O} *($ Step 15). The initial configuration is the same as the final state of $\mathrm{HCOOH}$ dehydrogenation. The $\mathrm{C}-\mathrm{OH}$ bond scission is exothermic by $0.83 \mathrm{eV}$ and requires an activation energy of $1.20 \mathrm{eV}$ (Figure S10). The $\mathrm{C}-\mathrm{OH}$ distance (Figure 8) changes by $0.19 \AA$ (B.I.S. $\rightarrow$ T.S.) and $2.91 \AA$ (T.S. $\rightarrow$ B.F.S.) The final $\mathrm{CO}(\mathrm{fcc})$ and $\mathrm{H}_{2} \mathrm{O}$ (top) are coadsorbed with a stabilization of about $0.1 \mathrm{eV}$ with respect to their co-adsorption at infinite separation.

${ }^{*} \mathrm{COOH}+\mathrm{CO}^{*} \rightarrow \mathrm{CO}_{2} *+\mathrm{HCO}^{*}($ Step 16). Co-adsorbed $\mathrm{COOH}$ (top) and $\mathrm{CO}$ (fec) in the initial state have no interaction. The $\mathrm{O}-\mathrm{H}$ bond scission is endothermic by $1.24 \mathrm{eV}$ and requires an activation energy barrier of $1.52 \mathrm{eV}$ (Figure S11). The O-H distance (Figure 8) changes from $0.99 \AA$ (B.I.S.) to 1.27 (T.S.) up to 2.15 (B.F.S.). The final state involves co- 
adsorption of $\mathrm{CO}_{2}$ (top) and $\mathrm{HCO}$ (top) which repel each other by $0.3 \mathrm{eV}$, compared to their coadsorption at infinite separation.

\subsubsection{CO oxidation and $\mathrm{H}_{2} \mathrm{O}$ formation}

$* \boldsymbol{C O}+\boldsymbol{O}^{*} \rightarrow \boldsymbol{C O}_{2} *+*($ Step 17). CO (hcp) and O (fcc) are co-adsorbed in the initial state with no interaction energy. The C-O bond formation is exothermic by $0.52 \mathrm{eV}$ and needs an activation energy of $1.40 \mathrm{eV}$ (Figure S12). The C-O distance (Figure 9) decreases from $4.30 \AA$ (B.I.S.) to $2.15 \AA$ (T.S.) down to $1.18 \AA$ (B.F.S.).

$\boldsymbol{O}^{*}+\boldsymbol{H}^{*} \rightarrow * \boldsymbol{O H}+*$ (Step 18). The co-adsorption of O (fcc) and H (hcp) leads to a destabilization of about $0.1 \mathrm{eV}$ with respect to their co-adsorption at infinite separation. The O$\mathrm{H}$ bond formation is exothermic by $0.30 \mathrm{eV}$ and requires an activation energy of $1.12 \mathrm{eV}$ (Figure S13). The O-H distance (Figure 9) decreases by $1.72 \AA$ (B.I.S. $\rightarrow$ T.S.) and $0.66 \AA$ (T.S. $\rightarrow$ B.F.S.).

$* \boldsymbol{O H}+* \boldsymbol{O H} \rightarrow \mathrm{H}_{2} \boldsymbol{O}^{*}+\boldsymbol{O} *$ (Step 19). The co-adsorption of OH (top) and OH (top) results in a stabilization of about $0.2 \mathrm{eV}$ with respect to their co-adsorption at infinite separation. The $\mathrm{O}-\mathrm{H}$ bond scission is exothermic by $0.30 \mathrm{eV}$ and is a nearly spontaneous process (Figure S14). The O-H distance (Figure 9) increases by $0.13 \AA$ (B.I.S. $\rightarrow$ T.S.) and $0.93 \AA$ (T.S. $\rightarrow$ B.F.S.). In the final state, $\mathrm{H}_{2} \mathrm{O}$ (top) and $\mathrm{O}(\mathrm{fcc})$ are co-adsorbed with a stabilization of more than $0.1 \mathrm{eV}$ with respect to their co-adsorption at infinite separation.

$$
\boldsymbol{H}^{*}+* \mathrm{OH} \rightarrow \mathrm{H}_{2} \mathrm{O}^{*}+* \text { (Step 20). The co-adsorption of H (fcc) and OH (fcc/bridge) }
$$

occurs with no interaction energy. The $\mathrm{O}-\mathrm{H}$ bond formation is exothermic by $0.51 \mathrm{eV}$ and has an activation energy barrier of $0.63 \mathrm{eV}$ (Figure S15). The O-H (Figure 9) distance is equal to $3.45 \AA$ (B.I.S.), $1.75 \AA$ (T.S.) and $0.99 \AA$ (B.F.S.). 
Table 3 shows that, starting from $\mathrm{HCOOH}$ adsorbed in the perpendicular configuration, $\mathrm{O}-\mathrm{H}$ bond scission (Step 1) is easier than C-H bond scission (Step 2); a strong repulsion between the final co-adsorbed products is observed in both cases. Further, $\mathrm{CO}_{2}$ formation from $\mathrm{HCOO}$ (Step 3) is more difficult than $\mathrm{CO}_{2}$ formation from $\mathrm{COOH}$ (Step 4) in agreement with the results of Yoo et al.[36]. The behavior of the two dehydrogenation paths, with HCOO formation being easier than $\mathrm{COOH}$ formation and $\mathrm{HCOO}$ decomposition being more difficult than $\mathrm{COOH}$ decomposition, is in agreement with findings from Lin et al.[58] who investigated WGS on different metal surfaces. In general, all our dehydrogenation barriers (Steps $1-4$ ) are smaller than those reported by $\mathrm{Hu}$ et al.[34] and Zhang et al.[37], perhaps because different transition state search methods have been used. The activation energy barrier found for $\mathrm{HCOO}$ decomposition is related to the formation of monodentate adsorbed $\mathrm{HCOO}$ which involves an OPd bond scission followed by C-H bond scission (see Figure 4a). The formation of the monodentate $\mathrm{HCOO}$ intermediate before the $\mathrm{C}-\mathrm{H}$ bond scission takes place agrees well with findings from both Hu et al.[34] and Zhang et al.[37].

The reaction between $\mathrm{HCOO}$ and $\mathrm{O}$ or $\mathrm{OH}$ (Step 9 and 10) leads to activation energy barriers for $\mathrm{C}-\mathrm{H}$ bond scission higher than that needed for $\mathrm{HCOO}$ dehydrogenation on the clean surface. By contrast, the presence of co-adsorbed $\mathrm{O}$ and $\mathrm{OH}$ facilitates $\mathrm{COOH}$ dehydrogenation (Step 13 and 14): this could be partially explained by the attractive interaction between the starting co-adsorbed species in the case of $\mathrm{COOH}+\mathrm{O}$ and $\mathrm{COOH}+\mathrm{OH}$. This stabilization is due to the acidity of the $\mathrm{H}$ atom in the $\mathrm{COOH}$ intermediate, in analogy with the acidic behavior of the hydroxyl hydrogen of formic acid which has been reported in several studies by Madix et al. (see e.g. ref.[59-62]). The different behavior of $\mathrm{COOH}$ and $\mathrm{HCOO}$ intermediates in presence of $\mathrm{O}$ and $\mathrm{OH}$ species is also in agreement with the behavior of ethanol on $\mathrm{Pd}$ as reported by Hibbitts et 
al.[63]. The reaction between $\mathrm{HCOO}$ or $\mathrm{COOH}$ and $\mathrm{CO}$, resulting in the formation of $\mathrm{CO}_{2}$ and HCO (Step 11 and 16), is unfavorable and is characterized by a repulsion between the coadsorbed products. The recombination of $\mathrm{HCOO}$ and $\mathrm{COOH}$ (Step 12), which occurs through O$\mathrm{H}$ bond scission, is slightly endothermic and requires a small activation energy.

The production of $\mathrm{CO}$ from $\mathrm{HCOOH}$ (Step 5 and 7) through $\mathrm{HCO}$ formation is difficult because of the large activation energy barrier to decompose $\mathrm{HCOOH}$ into $\mathrm{HCO}$ and $\mathrm{OH}$ (Step 5), which is similar to what we found for $\mathrm{HCOO}$ dissociation into $\mathrm{HCO}$ and $\mathrm{O}$ (Step 6): the barrier for $\mathrm{C}-\mathrm{OH}$ bond scission in $\mathrm{HCOOH}$ is smaller than that found by Zhang et al.[37] due perhaps to the different TS search methods used. Even if CO production from HCO is favorable (Step 7), this route seems to be unlikely since all the possible paths considered for HCO formation (Step 5, 6 and also 11 and 16) are characterized by high activation energies. By contrast, CO formation through $\mathrm{COOH}$ (Step 8) is easier. In particular, the direct $\mathrm{COOH}$ decomposition into $\mathrm{CO}$ is easier than $\mathrm{H}$-assisted $\mathrm{COOH}$ decomposition (Step 15). The subsequent $\mathrm{CO}$ oxidation (Step 17) is a difficult step because of the large activation energy barrier, which is in agreement with that calculated by García-Mota et al.[64] and Eichler[65] and slightly larger with respect to the measurements reported by Engel et al.[66].

Finally, the formation of $\mathrm{OH}$ may occur either through the reaction between co-adsorbed $\mathrm{O}$ and $\mathrm{H}$ (Step 18) or through $\mathrm{COOH}$ decomposition on the clean surface (Step 8) or in presence of co-adsorbed O (Step 13). The produced $\mathrm{OH}$ could react to form $\mathrm{H}_{2} \mathrm{O}$ through Steps 14, 19 and 20. The values of the activation energy barriers for $\mathrm{OH}$ and $\mathrm{H}_{2} \mathrm{O}$ formation are in reasonable agreement with the values reported by Phatak et al.[67], though they are larger than those obtained by Ford et al.[68], likely due to the different unit cell size used. 


\subsection{Potential energy surface of $\mathrm{HCOOH}$ decomposition on clean $\mathrm{Pd}(111)$}

The potential energy surface (PES) for $\mathrm{HCOOH}$ dehydrogenation and dehydration through $\mathrm{HCOO}$ and $\mathrm{COOH}$ intermediates on the clean $\mathrm{Pd}(111)$ surface is shown in Figure 10; both the co-adsorption and infinitely separated states are indicated. Figure 10 includes the following pathways: (a) $\mathrm{HCOOH}^{*} \rightarrow \mathrm{HCOO}^{*} \rightarrow \mathrm{CO}_{2} *$ (step 1 and 3); (b) $\mathrm{HCOOH}^{*} \rightarrow \mathrm{COOH}^{*} \rightarrow \mathrm{CO}_{2} *$ (step 2 and 4); (c) $\mathrm{HCOOH}^{*} \rightarrow \mathrm{HCOO}^{*} \rightarrow \mathrm{HCO}^{*} \rightarrow \mathrm{CO}^{*}$ (step 1, 6 and 7) and (d) $\mathrm{HCOOH}^{*} \rightarrow \mathrm{COOH}^{*} \rightarrow \mathrm{CO}^{*}$ (step 2 and 8). As reported in Section 3.2, the presence of coadsorbed $\mathrm{O}$ and $\mathrm{OH}$ species facilitates $\mathrm{COOH}$ dehydrogenation, whereas it makes $\mathrm{HCOO}$ decomposition into $\mathrm{CO}_{2}$ and $\mathrm{H}$ more difficult.

The PES shows that, based on the computed total energy, adsorbed $\mathrm{COOH}$ is more stable than adsorbed $\mathrm{HCOO}$. However, $\mathrm{HCOO}$ formation is easier than $\mathrm{COOH}$ formation because of the lower stability of $\mathrm{HCOOH}$ adsorbed in the nearly parallel configuration, which is the precursor state for $\mathrm{COOH}$ formation. Further, $\mathrm{HCOO}$ decomposition is more difficult than $\mathrm{COOH}$ decomposition. These two findings may suggest that formate may accumulate on the surface, which is in agreement with relevant experimental findings (see e.g. ref[4]). Depending on experimental conditions, both intermediates may contribute to $\mathrm{HCOOH}$ decomposition. $\mathrm{CO}_{2}$ formation is preferred to $\mathrm{CO}$ formation in both formate- and carboxyl-mediated routes. The production of $\mathrm{CO}$, however, should mainly proceed through $\mathrm{COOH}$ decomposition. In fact, one can argue that, based on the PES alone, adsorbed $\mathrm{HCOO}$ would be converted into $\mathrm{CO}_{2}$ while adsorbed $\mathrm{COOH}$ may decompose into both $\mathrm{CO}_{2}$ and $\mathrm{CO}$. The higher activation energy barriers characterizing $\mathrm{HCOO}$ decomposition compared to $\mathrm{COOH}$ decomposition, both on the clean surface and in presence of co-adsorbed species, such as $\mathrm{O}$ and $\mathrm{OH}$, may explain why only $\mathrm{HCOO}$ intermediate has been observed in experiments, as discussed in the introduction. 


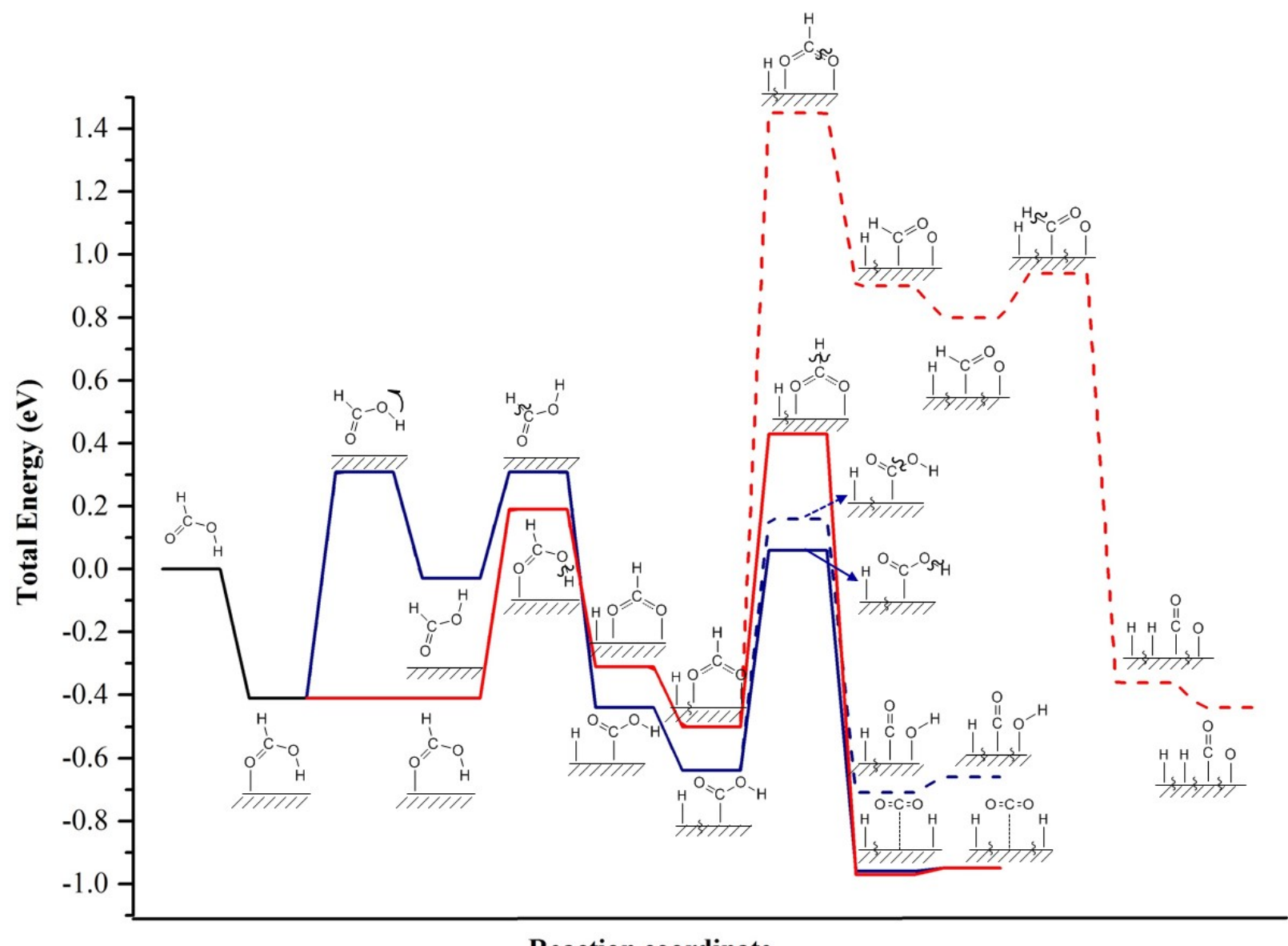

\section{Reaction coordinate}

Figure 10. Potential energy surface for reaction paths leading to $\mathrm{HCOOH}$ decomposition on the clean $\mathrm{Pd}(111)$ surface. Red and the blue lines indicate the $\mathrm{HCOO}$ and $\mathrm{COOH}$ paths respectively. Solid red line: $\mathrm{HCOOH}^{*} \rightarrow \mathrm{HCOO}^{*} \rightarrow \mathrm{CO}_{2} *$ (steps 1 and 3); solid blue line $\mathrm{HCOOH}^{*} \rightarrow \mathrm{COOH}^{*} \rightarrow \mathrm{CO}_{2} *$ (steps 2 and 4); dashed red line: $\mathrm{HCOOH}^{*} \rightarrow \mathrm{HCOO}^{*} \rightarrow \mathrm{HCO}^{*} \rightarrow \mathrm{CO}^{*}$ (steps 1, 6 and 7); dashed blue line: $\mathrm{HCOOH}^{*} \rightarrow \mathrm{COOH}^{*} \rightarrow \mathrm{CO}^{*}$ ( steps 2 and 8 ).

Symbol $\xi$ means infinite separation. The dashed line in the $\mathrm{CO}_{2}+2 \mathrm{H}$ state indicates that $\mathrm{CO}_{2}$ is physisorbed.

\section{Conclusion}

Periodic, self-consistent (GGA-PW91), Density Functional Theory calculations have been performed to investigate $\mathrm{HCOOH}$ decomposition on $\mathrm{Pd}(111)$ surface through $\mathrm{HCOO}$ and $\mathrm{COOH}$ intermediates. Possible elementary reaction steps have been studied both on the clean surface and 
in the presence of co-adsorbed species such as $\mathrm{O}, \mathrm{OH}$ and $\mathrm{CO}$. DFT results suggest that $\mathrm{HCOO}$ formation is easier than $\mathrm{COOH}$ formation, but $\mathrm{HCOO}$ decomposition is more difficult than $\mathrm{COOH}$ decomposition. We conclude that depending on reaction conditions, both $\mathrm{HCOO}$ and $\mathrm{COOH}$ routes may contribute to $\mathrm{HCOOH}$ decomposition. $\mathrm{CO}_{2}$ formation is in general preferred to $\mathrm{CO}$ formation, the latter occurring mainly through $\mathrm{COOH}$ decomposition on the clean surface. Co-adsorbed $\mathrm{O}$ and $\mathrm{OH}$ facilitate $\mathrm{CO}_{2}$ formation from $\mathrm{COOH}$; by contrast, these co-adsorbed species make $\mathrm{CO}_{2}$ formation from $\mathrm{HCOO}$ more difficult. The effect of high coverage of coadsorbed $\mathrm{CO}$ on the reaction mechanisms is currently under consideration. Finally, a comparison between DFT-derived microkinetic modeling results and experimental reaction kinetics data, should shed further light into the detailed reaction mechanism for $\mathrm{HCOOH}$ decomposition over a range of relevant experimental reaction conditions.

\section{ACKNOWLEDGEMENTS}

Both authors have been inspired by the pioneering mechanistic work of Prof. Madix in the field of surface science of catalytic reactions, and wish to dedicate this publication to his lifelong scientific accomplishments. We thank Y. Bai for his thoughtful comments on the manuscript. Research supported as part of the Institute for Atom-efficient Chemical Transformations (IACT), an Energy Frontiers Research Center funded by the U.S. Department of Energy, Office of Science, Office of Basic Energy Sciences (BES). Additional funds were provided by DOE-BES, Office of Chemical Sciences (Grant \# DE-FG02-05ER15731). The computational work was performed in part using supercomputing resources from the following institutions: EMSL, a National scientific user facility at Pacific Northwest National Laboratory (PNNL); the Center for Nanoscale Materials at Argonne National Laboratory (ANL); and the 
National Energy Research Scientific Computing Center (NERSC). EMSL is sponsored by the Department of Energy's Office of Biological and Environmental Research located at PNNL. CNM, and NERSC are supported by the U.S. Department of Energy, Office of Science, under contracts DE-AC02-06CH11357, and DE-AC02-05CH11231, respectively. 


\section{REFERENCES}

[1] M.A. Barteau, Linear Free-Energy Relationships for C1-Oxygenate Decomposition on TransitionMetal Surfaces, Catalysis Letters, 8 (1991) 175-184.

[2] J.Q. Bond, D.M. Alonso, D. Wang, R.M. West, J.A. Dumesic, Integrated Catalytic Conversion of gamma-Valerolactone to Liquid Alkenes for Transportation Fuels, Science, 327 (2010) 1110-1114.

[3] J.P. Lange, R. Price, P.M. Ayoub, J. Louis, L. Petrus, L. Clarke, H. Gosselink, Valeric Biofuels: A Platform of Cellulosic Transportation Fuels, Angewandte Chemie-International Edition, 49 (2010) 44794483.

[4] W.M.H. Sachtler, Fahrenfort.J, The catalytic decomposition of formic acid vapour on metals, Proceedings, 2nd International Congress on Catalysis, Technip, Paris, 1960, pp. p. 831.

[5] S. Ha, R. Larsen, R.I. Masel, Performance characterization of $\mathrm{Pd} / \mathrm{C}$ nanocatalyst for direct formic acid fuel cells, Journal of Power Sources, 144 (2005) 28-34.

[6] N.M. Markovic, P.N. Ross, Surface science studies of model fuel cell electrocatalysts, Surface Science Reports, 45 (2002) 121-229.

[7] Y.H. Pan, R.M. Zhang, S.L. Blair, Anode Poisoning Study in Direct Formic Acid Fuel Cells, Electrochemical and Solid State Letters, 12 (2009) B23-B26.

[8] E. Antolini, Palladium in fuel cell catalysis, Energy \& Environmental Science, 2 (2009) 915-931.

[9] C.M. Miesse, W.S. Jung, K.J. Jeong, J.K. Lee, J. Lee, J. Han, S.P. Yoon, S.W. Nam, T.H. Lim, S.A. Hong, Direct formic acid fuel cell portable power system for the operation of a laptop computer, Journal of Power Sources, 162 (2006) 532-540.

[10] C. Rice, S. Ha, R.I. Masel, A. Wieckowski, Catalysts for direct formic acid fuel cells, Journal of Power Sources, 115 (2003) 229-235.

[11] S. Ha, B. Adams, R.I. Masel, A miniature air breathing direct formic acid fuel cell, Journal of Power Sources, 128 (2004) 119-124.

[12] X.W. Yu, P.G. Pickup, Recent advances in direct formic acid fuel cells (DFAFC), Journal of Power Sources, 182 (2008) 124-132.

[13] J.H. Choi, K.J. Jeong, Y. Dong, J. Han, T.H. Lim, J.S. Lee, Y.E. Sung, Electro-oxidation of methanol and formic acid on PtRu and PtAu for direct liquid fuel cells, Journal of Power Sources, 163 (2006) 71-75.

[14] M.J. Llorca, J.M. Feliu, A. Aldaz, J. Clavilier, Formic-Acid Oxidation on Pd-Ad Plus Pt(100) and Pd-Ad Plus Pt(111) Electrodes, Journal of Electroanalytical Chemistry, 376 (1994) 151-160.

[15] Y.X. Chen, S. Ye, M. Heinen, Z. Jusys, M. Osawa, R.J. Behm, Application of in-situ attenuated total reflection-Fourier transform infrared spectroscopy for the understanding of complex reaction mechanism and kinetics: Formic acid oxidation on a Pt film electrode at elevated temperatures, Journal of Physical Chemistry B, 110 (2006) 9534-9544.

[16] Y.X. Chen, M. Heinen, Z. Jusys, R.J. Behm, Kinetics and mechanism of the electrooxidation of formic acid - Spectroelectrochemical studies in a flow cell, Angewandte Chemie-International Edition, 45 (2006) 981-985.

[17] Y.X. Chen, M. Heinen, Z. Jusys, R.J. Behm, Kinetic isotope effects in complex reaction networks: Formic acid electro-oxidation, Chemphyschem, 8 (2007) 380-385.

[18] Y.X. Chen, M. Heinen, Z. Jusys, R.J. Behm, Bridge-bonded formate: Active intermediate or spectator species in formic acid oxidation on a Pt film electrode?, Langmuir, 22 (2006) 10399-10408.

[19] K.H. Kim, J.K. Yu, H.S. Lee, J.H. Choi, S.Y. Noh, S.K. Yoon, C.S. Lee, T.S. Hwang, Y.W. Rhee, Preparation of Pt-Pd catalysts for direct formic acid fuel cell and their characteristics, Korean Journal of Chemical Engineering, 24 (2007) 518-521.

[20] A. Capon, R. Parsons, Oxidation of Formic-Acid at Noble-Metal Electrodes .1. Review of Previous Work, Journal of Electroanalytical Chemistry, 44 (1973) 1-7.

[21] A. Capon, R. Parsons, Oxidation of Formic-Acid at Noble-Metal Electrodes Part .3. Intermediates and Mechanism on Platinum-Electrodes, Journal of Electroanalytical Chemistry, 45 (1973) 205-231. 
[22] N. Hoshi, K. Kida, M. Nakamura, M. Nakada, K. Osada, Structural effects of electrochemical oxidation of formic acid on single crystal electrodes of palladium, Journal of Physical Chemistry B, 110 (2006) 12480-12484.

[23] K. Nishimura, K. Kunimatsu, K. Machida, M. Enyo, Electrocatalysis of Pd + Au Alloy Electrodes .4. Ir Spectroscopic Studies on the Surface Species Derived from Formaldehyde and Formate in AlkalineSolutions, Journal of Electroanalytical Chemistry, 260 (1989) 181-192.

[24] M. Arenz, V. Stamenkovic, T.J. Schmidt, K. Wandelt, P.N. Ross, N.M. Markovic, The electrooxidation of formic acid on Pt-Pd single crystal bimetallic surfaces, Physical Chemistry Chemical Physics, 5 (2003) 4242-4251.

[25] J.Y. Wang, H.X. Zhang, K. Jiang, W.B. Cai, From HCOOH to CO at Pd Electrodes: A SurfaceEnhanced Infrared Spectroscopy Study, Journal of the American Chemical Society, 133 (2011) 1487614879.

[26] T. Zheng, D. Stacchiola, D.K. Saldin, J. James, D.S. Sholl, W.T. Tysoe, The structure of formate species on $\operatorname{Pd}(111)$ calculated by density functional theory and determined using low energy electron diffraction, Surface Science, 574 (2005) 166-174.

[27] S. Pronkin, M. Hara, T. Wandlowski, Electrocatalytic properties of Au(111)-Pd quasi-single-crystal film electrodes as probed by ATR-SEIRAS, Russian Journal of Electrochemistry, 42 (2006) 1177-1192.

[28] A. Miki, S. Ye, M. Osawa, Surface-enhanced IR absorption on platinum nanoparticles: an application to real-time monitoring of electrocatalytic reactions, Chemical Communications, (2002) 15001501.

[29] G. Samjeske, A. Miki, S. Ye, A. Yamakata, Y. Mukouyama, H. Okamoto, M. Osawa, Potential oscillations in galvanostatic electrooxidation of formic acid on platinum: A time-resolved surfaceenhanced infrared study, Journal of Physical Chemistry B, 109 (2005) 23509-23516.

[30] G. Samjeske, M. Osawa, Current oscillations during formic acid oxidation on a Pt electrode: Insight into the mechanism by time-resolved IR spectroscopy, Angewandte Chemie-International Edition, 44 (2005) 5694-5698.

[31] G. Samjeske, A. Miki, S. Ye, M. Osawa, Mechanistic study of electrocatalytic oxidation of formic acid at platinum in acidic solution by time-resolved surface-enhanced infrared absorption spectroscopy, Journal of Physical Chemistry B, 110 (2006) 16559-16566.

[32] M.E. Vela, R.O. Lezna, N.R. Detacconi, A.J. Arvia, B. Beden, F. Hahn, C. Lamy, Emirs Studies of Formic-Acid Electrooxidation on $\mathrm{Pd}, \mathrm{Au}$ and $\mathrm{Pd}+\mathrm{Au}$ Alloys .1. Investigation of the Adsorbates Derived from Hcooh and Nacooh Chemisorption at $\mathrm{Pd}$ in Acid and Alkaline-Solutions, Journal of Electroanalytical Chemistry, 323 (1992) 289-302.

[33] S.D. Zhou, C. Qian, X.Z. Chen, Comparative Theoretical Study of Adsorption and Dehydrogenation of Formic Acid, Hydrazine and Isopropanol on Pd(111) Surface, Catalysis Letters, 141 (2011) 726-734.

[34] C.T.S.-W.C. Hu, K.-Y.; Huang W., Reaction pathways derived from DFT for understanding catalytic decomposition of formic acid into hydrogen on noble metals, International Journal of Hydrogen Energy, 37 (2012) 10.

[35] Y. Wang, Y. Qi, D. Zhang, New mechanism of the direct pathway for formic acid oxidation on $\operatorname{Pd}(111)$, Computational and Theoretical Chemistry, 1049 (2014) 51-54.

[36] J.S. Yoo, F. Abild-Pedersen, J.K. Nørskov, F. Studt, Theoretical analysis of transition-metal catalysts for formic acid decomposition, ACS Catalysis, 4 (2014) 1226-1233.

[37] R. Zhang, H. Liu, B. Wang, L. Ling, Insights into the preference of CO 2 formation from $\mathrm{HCOOH}$ decomposition on Pd surface: A theoretical study, Journal of Physical Chemistry C, 116 (2012) 2226622280.

[38] J.K. Nørskov, J. Rossmeisl, A. Logadottir, L. Lindqvist, J.R. Kitchin, T. Bligaard, H. Jónsson, Origin of the Overpotential for Oxygen Reduction at a Fuel-Cell Cathode, The Journal of Physical Chemistry B, 108 (2004) 17886-17892.

[39] B. Hammer, L.B. Hansen, J.K. Norskov, Improved adsorption energetics within density-functional theory using revised Perdew-Burke-Ernzerhof functionals, Physical Review B, 59 (1999) 7413-7421. 
[40] J. Greeley, J.K. Norskov, M. Mavrikakis, Electronic structure and catalysis on metal surfaces, Annual Review of Physical Chemistry, 53 (2002) 319-348.

[41] J. Greeley, M. Mavrikakis, Competitive Paths for Methanol Decomposition on Pt(111), Journal of the American Chemical Society, 126 (2004) 3910-3919.

[42] J. Greeley, M. Mavrikakis, A First-Principles Study of Methanol Decomposition on Pt(111), Journal of the American Chemical Society, 124 (2002) 7193-7201.

[43] A. Michaelides, P. Hu, Insight into microscopic reaction pathways in heterogeneous catalysis [16], Journal of the American Chemical Society, 122 (2000) 9866-9867.

[44] A. Michaelides, P. Hu, Catalytic water formation on platinum: A first-principles study, Journal of the American Chemical Society, 123 (2001) 4235-4242.

[45] D. Vanderbilt, Soft Self-Consistent Pseudopotentials in a Generalized Eigenvalue Formalism, Physical Review B, 41 (1990) 7892-7895.

[46] D.J. Chadi, M.L. Cohen, Special Points in the Brillouin Zone, Physical Review B, 8 (1973) 57475753.

[47] J.P. Perdew, J.A. Chevary, S.H. Vosko, K.A. Jackson, M.R. Pederson, D.J. Singh, C. Fiolhais, Atoms, Molecules, Solids, and Surfaces - Applications of the Generalized Gradient Approximation for Exchange and Correlation, Physical Review B, 46 (1992) 6671-6687.

[48] J.A. White, D.M. Bird, Implementation of Gradient-Corrected Exchange-Correlation Potentials in Car-Parrinello Total-Energy Calculations, Physical Review B, 50 (1994) 4954-4957.

[49] CRC Handbook of Chemistry and Physics, CRC Press, New York, 1996.

[50] J.A. Herron, J. Scaranto, P. Ferrin, S. Li, M. Mavrikakis, Trends in Formic Acid Decomposition on Model Transition Metal Surfaces: A Density Functional Theory study, ACS Catalysis, 4 (2014) 44344445.

[51] A. Ulitsky, R. Elber, A New Technique to Calculate Steepest Descent Paths in Flexible Polyatomic Systems, Journal of Chemical Physics, 92 (1990) 1510-1511.

[52] G. Mills, H. Jonsson, G.K. Schenter, Reversible Work Transition-State Theory - Application to Dissociative Adsorption of Hydrogen, Surface Science, 324 (1995) 305-337.

[53] G. Henkelman, B.P. Uberuaga, H. Jonsson, A climbing image nudged elastic band method for finding saddle points and minimum energy paths, Journal of Chemical Physics, 113 (2000) 9901-9904.

[54] J. Greeley, M. Mavrikakis, A first-principles study of surface and subsurface H on and in Ni(lllll 111$)$ : diffusional properties and coverage-dependent behavior, Surface Science, 540 (2003) 215-229.

[55] L.C. Grabow, A.A. Gokhale, S.T. Evans, J.A. Dumesic, M. Mavrikakis, Mechanism of the water gas shift reaction on Pt: First principles, experiments, and microkinetic modeling, Journal of Physical Chemistry C, 112 (2008) 4608-4617.

[56] P. Ferrin, M. Mavrikakis, Structure Sensitivity of Methanol Electrooxidation on Transition Metals, Journal of the American Chemical Society, 131 (2009) 14381-14389.

[57] W. Dong, G. Kresse, J. Hafner, Dissociative adsorption of H2 on the Pd(111) surface, Journal of Molecular Catalysis A: Chemical, 119 (1997) 69-76.

[58] C.H. Lin, C.L. Chen, J.H. Wang, Mechanistic Studies of Water-Gas-Shift Reaction on Transition Metals, Journal of Physical Chemistry C, 115 (2011) 18582-18588.

[59] M. Bowker, R.J. Madix, XPS, UPS and thermal desorption studies of the reactions of formaldehyde and formic acid with the $\mathrm{Cu}(110)$ surface, Surface Science, 102 (1981) 542-565.

[60] B.A. Sexton, R.J. Madix, A vibrational study of formic acid interaction with clean and oxygencovered silver (110) surfaces, Surface Science, 105 (1981) 177-195.

[61] E.M. Silverman, R.J. Madix, C.R. Brundle, FORMIC ACID DECOMPOSITION FROM CLEAN AND OXIDIZED NICKEL/IRON (100) ALLOY SURFACES, Journal of vacuum science \& technology, 18 (1980) 616-619.

[62] D.H.S. Ying, J.M. Robert, Thermal desorption study of formic acid decomposition on a clean $\mathrm{Cu}(110)$ surface, Journal of Catalysis, 61 (1980) 48-56. 
[63] D.D. Hibbitts, M. Neurock, Influence of oxygen and $\mathrm{pH}$ on the selective oxidation of ethanol on Pd catalysts, Journal of Catalysis, 299 (2013) 261-271.

[64] M. Garcia-Mota, N. Lopez, The role of long-lived oxygen precursors on AuM alloys (M = Ni, Pd, Pt) in CO oxidation, Physical Chemistry Chemical Physics, 13 (2011) 5790-5797.

[65] A. Eichler, $\mathrm{CO}$ oxidation on transition metal surfaces: reaction rates from first principles, Surface Science, 498 (2002) 314-320.

[66] T. Engel, G. Ertl, Molecular-Beam Investigation of Catalytic-Oxidation of Co on Pd (111), Journal of Chemical Physics, 69 (1978) 1267-1281.

[67] A.A. Phatak, W.N. Delgass, F.H. Ribeiro, W.F. Schneider, Density Functional Theory Comparison of Water Dissociation Steps on $\mathrm{Cu}, \mathrm{Au}, \mathrm{Ni}, \mathrm{Pd}$, and Pt, Journal of Physical Chemistry C, 113 (2009) 7269-7276.

[68] D.C. Ford, A.U. Nilekar, Y. Xu, M. Mavrikakis, Partial and complete reduction of O(2) by hydrogen on transition metal surfaces, Surface Science, 604 (2010) 1565-1575. 